Review Article

\title{
Biomedical Properties of a Natural Dietary Plant Metabolite, Zerumbone, in Cancer Therapy and Chemoprevention Trials
}

\author{
Heshu Sulaiman Rahman, ${ }^{1,2,3}$ Abdullah Rasedee, ${ }^{1,2}$ \\ Swee Keong Yeap, ${ }^{2}$ Hemn Hassan Othman, ${ }^{1,3}$ Max Stanley Chartrand, ${ }^{4}$ \\ Farideh Namvar, ${ }^{5}$ Ahmad Bustamam Abdul, ${ }^{2}$ and Chee Wun How ${ }^{2}$ \\ ${ }^{1}$ Department of Veterinary Clinical Diagnosis, Faculty of Veterinary Medicine, Universiti Putra Malaysia (UPM), \\ 43400 Serdang, Selangor, Malaysia \\ ${ }^{2}$ Institute of Bioscience, Universiti Putra Malaysia (UPM), 43400 Serdang, Selangor, Malaysia \\ ${ }^{3}$ Department of Microbiology, Faculty of Veterinary Medicine, University of Sulaimanyah, Sulaymaniyah, Kurdistan Region, Iraq \\ ${ }^{4}$ DigiCare Behavioral Research, Casa Grande, AZ, USA \\ ${ }^{5}$ Institute of Tropical Forestry and Forest Products (INTROP), Universiti Putra Malaysia (UPM), 43400 Serdang, Selangor, Malaysia
}

Correspondence should be addressed to Heshu Sulaiman Rahman; heshusr77@gmail.com and Abdullah Rasedee; rasedee@vet.upm.edu.my

Received 27 March 2014; Revised 19 May 2014; Accepted 20 May 2014; Published 16 June 2014

Academic Editor: Gautam Sethi

Copyright (c) 2014 Heshu Sulaiman Rahman et al. This is an open access article distributed under the Creative Commons Attribution License, which permits unrestricted use, distribution, and reproduction in any medium, provided the original work is properly cited.

\begin{abstract}
Zerumbone (ZER) is a naturally occurring dietary compound, present in many natural foods consumed today. The compound derived from several plant species of the Zingiberaceae family that has been found to possess multiple biomedical properties, such as antiproliferative, antioxidant, anti-inflammatory, and anticancer activities. However, evidence of efficacy is sparse, pointing to the need for a more systematic review for assessing scientific evidence to support therapeutic claims made for ZER and to identify future research needs. This review provides an updated overview of in vitro and in vivo investigations of ZER, its cancer chemopreventive properties, and mechanisms of action. Therapeutic effects of ZER were found to be scientifically plausible and could be explained partially by in vivo and in vitro pharmacological activities. Much of the research outlined in this paper will serve as a foundation to explain ZER anticancer bioactivity, which will open the door for the development of strategies in the treatment of malignancies using ZER.
\end{abstract}

\section{Introduction}

Medical herbs and plant foods such as fruits, vegetables, and spices contain many biologically active phytochemicals that have various health-promoting effects [1]. The Zingiberaceae family found in tropical and subtropical regions of the world and approximately 161 species from 18 genera of this family are found in Peninsular Malaysia [2]. Zingiber zerumbet (L.) Smith tree (Figure 1(a)), belonging to this family, is an edible ginger, originating in South-East Asia, and has been cultivated for thousands of years as a spice and for medical purposes [3]. Although this plant is known to be indigenous to India and the Malay Peninsula, it is nonetheless distributed in many other countries including Indonesia, China, Bangladesh, Vietnam, Japan, Burma, Nepal, Sri Lanka, Jamaica, and Nigeria and other parts of the globe [4]. This herbal plant is popularly referred to as the pinecone, wild ginger, Asian ginger, or shampoo ginger. It is also called by many other names in different countries, such as lempoyang in Malaysia and Indonesia; parsu kedar, ghatian, and yaiimu in India [5], jangliadah in Bangladesh [6], hong qui jiang in China, haeo dam in Northern Thailand, awapuhiin in Hawaii, and zurunbah in the Middle East [3]. Generally, the rhizome and the leaves are used for spice, tea, beverage, and medical purposes, while the milky, mucilaginous substance of the inflorescences (pinecones) (Figure 1(b)) is famously used as a 


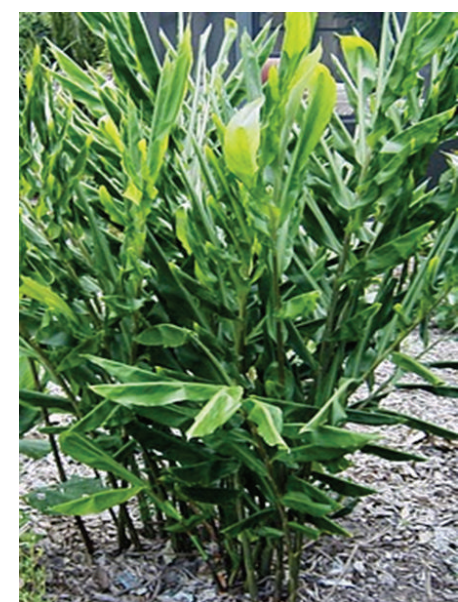

(a)

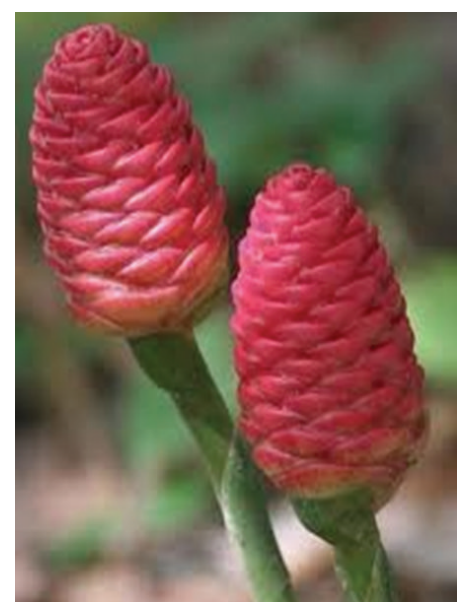

(b)

FIGURE 1: Zingiber zerumbet tree (a) and inflorescences (b).

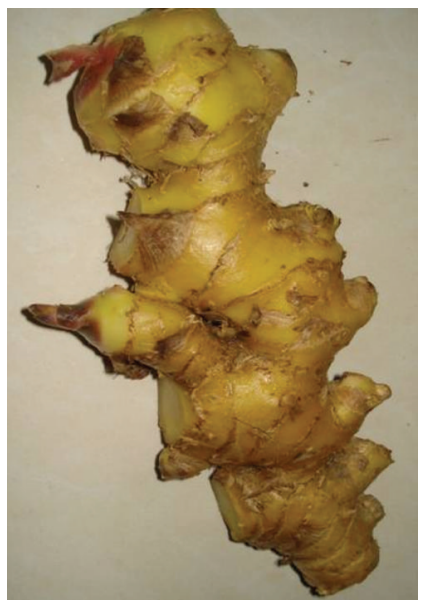

(a)

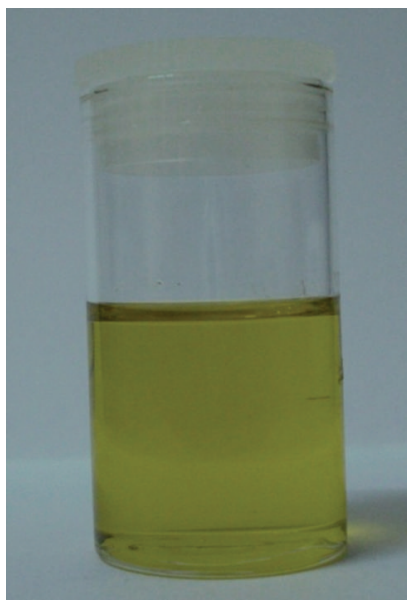

(b)

FIGURE 2: Zingiber zerumbet rhizome (a) and essential oil (b).

shampoo and natural hair conditioner, especially in Asia and Hawaii $[7,8]$.

Zingiber zerumbet contains several types of phytochemical and is considered as one of the most widely used traditional dietary condiments in various cuisines and beverages throughout Asia, although the essential oil is also used as perfume and in other toiletry articles [9]. Besides its extensive use as a spice, the rhizome particularly has been used in traditional oriental medicine for many human disorders, especially in the treatment of a variety of digestive conditions $[10,11]$. The rhizome and oils from the leaves of Zingiber zerumbet have been subjected to close chemical scrutiny for their medicinal value [12].

Ginger is generally recognized as safe and is used traditionally in local folk medicine for treatment of nausea, hangovers, asthma, morning and motion sickness, loss of appetite, dyspepsia, diarrhea, colic, cramp, stomach upset, sprain, worm infestation in children, cough and cold, flu, sinusitis, catarrh, congestion, sore throat, migraine headache, toothache, diabetes, bruising, carbuncles, fracture, swelling, rheumatism, arthritis, and chills and fever [13-15].

Presently, rhizome's extract has been extensively studied for its effectiveness in a broad range of biological activities including antimicrobial [16], antipyretic [17], antispasmodic and anticonvulsant [3], antiulcer [18], antioxidant [19], antidiabetic [20], antitumor [21], anticancer [22, 23], antiinflammatory [24, 25], antinociceptive and analgesic [26, 27], antiallergenic [28], antiangiogenic [29], antidipogenetic [30], antiplatelet aggregation and anticoagulant [31], and hepatoprotective effects [32]. Other studies have shown that consuming the rhizome also exhibits hypolipidemic effect by reducing intestinal cholesterol absorption, which makes it useful for treating heart diseases $[33,34]$.

The essential oil of Zingiber zerumbet rhizome (Figure 2(a)) contains approximately $86 \%$ sesquiterpenoids [35] while the leaf and rhizome oils (Figure 2(b)) of this plant 


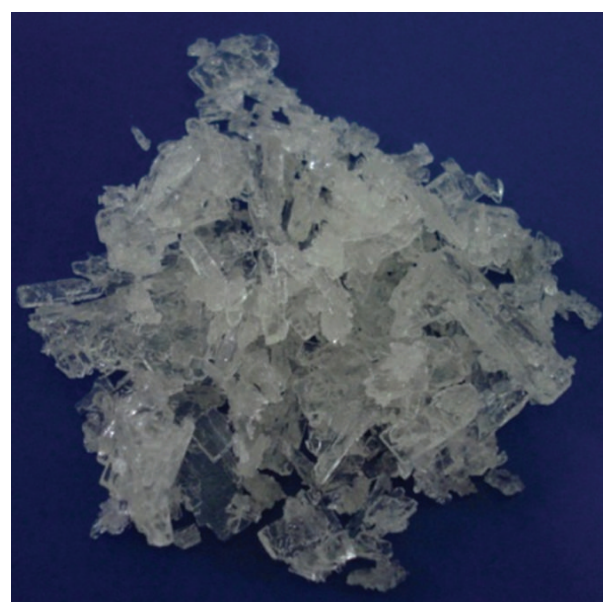

(a)

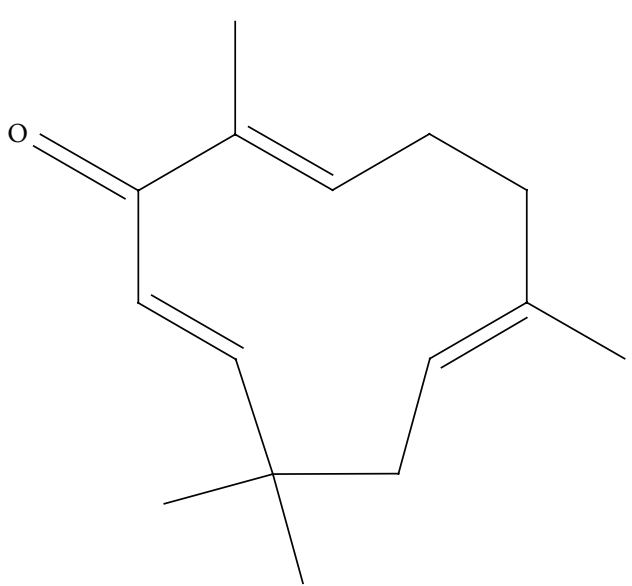

(b)

Figure 3: Zerumbone pure crystals (a) and chemical structure (b).

contain a complex mixture of 29 and 30 compounds, respectively [6]. Many of these compounds are in trace amounts with great variations in their chemical compositions.

Zerumbone (Figure 3(a)) was first isolated from the essential volatile oil of rhizomes of Zingiber zerumbet in 1956 [36], while its chemical structure (Figure 3(b)) was determined in 1960 and later characterized by NMR and $\mathrm{X}$-ray [37]. Zerumbone possesses three double bonds, two conjugated and one isolated, as well as double conjugated carbonyl group in the 11-membrane ring structure [38]. The chemical characteristics of ZER are presented in Table 1 [3943].

\section{Plant Sources of Zerumbone}

Early investigations in different parts of the world showed that 12.6 to $73.1 \%$ of ZER in Zingiber zerumbet is in the rhizome oils [44]. The Kerala state in the South Indian accessions reported that in Zingiber zerumbet 76.3 to $84.8 \%$ of its ZER content is also in the rhizome oils [44]. On the other hand, a silviculture farm in India reported that $1.81 \%$ ZER content was found in the rhizome, $0.16 \%$ in the root, $0.09 \%$ in the leaf, and $0.03 \%$ in the flower of Zingiber zerumbet [5]. The Penang Malaysian accession recorded the content of ZER in the plant at $68.9 \%$ [44]. Another study conducted in the state of Selangor, Malaysia, showed that the ZER content of Zingiber zerumbet is $1.3 \mathrm{~g} / \mathrm{kg}$ rhizome [23]. The oils of Zingiber zerumbet from Tahiti Island and Vietnam were also found to be rich in ZER at 65.3 and 72.3 , respectively $[45,46]$. In Vietnam, ZER was also isolated from the rhizomes of the Vietnamese Curcuma zedoaria (Berg.) Roscoe [47]. Other reports on the ginger plant include that by Chane-Ming et al. [48] and Bhuiyan et al. [6] each showing the rhizome to contain approximately $37 \%$ of the plant ZER content. The differences in ZER content in the plant are not due to geographic or ecological variations but instead because of differences in ZER chemotype [3].
Other ginger plant species with ZER among their constituents include the Zingiber amaricans [49], Zingiber ottensii Valeton [50], Zingiber aromaticum (17.72\%) [51], Zingiber cassumunar Roxb. (1\%) [52], Zingiber ottensii [53], and Zingiber montanum [18]. Various other plants also contain ZER; among them are Curcuma amada Roxb. [35] from India, Alpinia galanga from Sri Lanka [54], and Xylopia aethiopica from Ibadan, Southwest Nigeria [55].

\section{Anticancer Properties of Zerumbone}

Several researchers have reported that ZER has both in vitro (Table 2) and in vivo (Table 3 ) anticancer properties at different concentrations and doses [56]. Zerumbone possesses antiproliferative properties towards several cancer cell lines with minimal effect on normal cells [57-59]. Among the effects of ZER is induction of high intracellular redox potential that can inhibit proliferation of cancer cells [60]. The cytotoxic effect of ZER on the cancer cells appears to be attributed to the versatile $\alpha, \beta$-unsaturated carbonyl group in its structure, which plays an important role in the interaction of the compound with the most biologically active molecules. Clearly the carbonyl group is important for biological activity because $\alpha$-humulene, also found in ginger, lacking in this functional group is virtually and consistently pharmacological inactive [61]. The $\alpha, \beta$-unsaturated carbonyl group in ZER effectively removes the intracellular glutathione (GSH) through the formation of Michael adducts, thus enhancing the potential of intracellular redox (E), resulting in the inhibition of spread of cancerous cells. However, the average intracellular redox potential of normal cells differs from that of cancerous cells; this difference could be the reason for ZER not inducing proliferation of normal cells $[60,61]$. Because there is a close link between tumor promotion, inflammation, and oxidative stress, the antiinflammatory and/or antioxidant compounds could also act as an anticarcinogenic agent [62]. Although the stimulation of neoplastic cell death by ZER was reported to be through 
TABLE 1: Characteristic features of zerumbone.

\begin{tabular}{lc}
\hline Characters & Description \\
\hline Natural occurrence & Zingiber species \\
Chemical class & Sesquiterpene \\
Chemical formula & $(2 \mathrm{E}, 6 \mathrm{E}, 10 \mathrm{E})-2,6,9,9-$ \\
Molecular formula & tetramethylcycloundeca-2,6,10- \\
& $\mathrm{C}_{15} \mathrm{H}_{22} \mathrm{O}$
\end{tabular}

the mitochondrial pathway of apoptosis [47], it also exhibits antiproliferative and anti-inflammatory activities through the modulation of NF- $\kappa$ B activity. Zerumbone inhibits NF- $\kappa$ B in association with the sequential suppressions of $\mathrm{I} \kappa \mathrm{B} \alpha$ kinase activity, phosphorylation, and degradation. This compound also inhibits NF- $\kappa \mathrm{B}$-dependent reporter gene expression activated by TNF, TNFR1, TRADD, TRAF2, NIK, and IKK but not by the 655 subunit of NF- $\kappa$ B. Zerumbone also downregulates NF- $\kappa \mathrm{B}$-regulated gene products, including cyclin D1, COX-2, MMP-9, ICAM-1, c-myc, survivin, IAP1, IAP2, XIAP, Bcl-2, Bcl-xL, Bfl-1/A1, TRAF1, and FLIP. These effects lead to the potentiation of apoptosis induced by cytokines and chemotherapeutic agents. The inhibition of these NF$\kappa \mathrm{B}$-regulated genes expression is in association with the suppression of TNF-induced cancer invasiveness. Thus, it is hypothesized that inhibition of NF- $\kappa \mathrm{B}$ and NF- $\kappa \mathrm{B}$-regulated gene expression induced by carcinogens may also represent the molecular basis for cancer prevention and treatment by ZER [63]. Furthermore, it was shown that ZER is a novel inhibitor of CXC chemokine receptor-4 (CXCR4) expression, which mediates homing of tumor cells to specific organs during metastasis, suggesting the potential of the compound in the suppression of metastasis [64]. This receptor has been identified in various tumors including those in the breast, ovary, prostate, gastrointestinal tract, head, neck, bladder, brain, and skin.

3.1. Blood Cancer (Leukemia). It has been shown that ZER effectively suppresses the tumor promoter 12-Otetradecanoylphorbol-13-acetate- (TPA-) induced superoxide anion $\left(\mathrm{O}_{2}{ }^{-}\right)$generation from NADP oxidase in dimethyl sulfoxide- (DMSO-) differentiated human acute promyelocytic leukemia (HL-60) cells [60]. One study determined the effect of diethyl ether extract of Zingiber zerumbet fresh rhizome on cultured P-388D1 cells and in P-388D-bearing CDF mice. This study showed that the extract could induce DNA fragmentation in P-388D1 cells in vitro and significantly prolonged the life of P-388D1-bearing CDF mice. The same result was obtained when the activity of ZER isolated from the same extract was examined in vitro and in vivo [69]. The study further found that ZER inhibited the growth of HL-60 cells, in time- and concentration-dependent manner. HL-60 cell cycle analysis after treatment with ZER showed induction of G2/M arrest and decreased cyclin B1/CDK1 protein level. Using CEM-ss cells as targets, it was shown that ZER increased the number of TUNEL-positive cells and cellular caspase-3 level; the hallmarks of apoptosis [65]. The anticancer effects of ZER seem boundless when it was shown that it inhibits the proliferation of NB4 cell line, derived from acute promyelocytic leukemia cells, through the induction of $\mathrm{G} 2 / \mathrm{M}$ phase cell cycle arrest associated with a decline of cyclinB1 protein and phosphorylation of ATM/Chk1. The study indicated that ZER induction of NB4 cell apoptosis was initiated by the expression of Fas (CD95)/Fas ligand (CD95L), concomitant with the activation of caspase-8. At the same time, they found that ZER induced cleavage of Bid, Bax, and Mcl-1 proteins, phosphorylation of Cdc25C and Cdc 2 at the Thr48 and Thr14/Tyr15 residues, respectively, degradation of the proteolytic poly-(ADP-ribose) polymerase (PARP), and triggering of cytochrome $c$ release into the cytoplasm [69]. On leukemic cells, ZER is cytotoxic to human myeloid (KBM-5) [67], mouse myelomonocytic (WEHI-3B) [126], and human acute lymphoblastic leukemic (Jurkat) cell lines [66]. Zerumbone also regulates expression of apoptotic biomarkers in $\mathrm{BALB} / \mathrm{c}$ mice model of acute myelocytic leukemia via the mitochondrial intrinsic pathway [70].

3.2. Skin Cancer. Zerumbone suppressed 7,12-dimethylbenz $[\alpha]$ anthracene- (DMBA-) and TPA-induced initiation and promotion of skin tumors in female ICR mice. Using RT-PCR, it was shown that ZER enhances expression of manganese superoxide dismutase (MnSOD), glutathione peroxidase-1 (GPX-1), glutathione S-transferase-P1, and NAD (P) H quinine oxidoreductase (NQO1) mRNA in the epidermis while diminishing TPA-induced COX-2 protein expression and phosphorylation of extracellular signal-regulated kinase 1 and 2 (ERK1/2) [127]. The phorbol ester-induced papilloma formation in mouse skin can also be inhibited by 
TABLE 2: In Vitro biological effects of zerumbone.

\begin{tabular}{lll}
\hline Organ & Cell line & Biological effect of ZER \\
\hline $\begin{array}{l}\text { Human acute lymphocytic leukemia } \\
\text { (CEM-ss) [65] }\end{array}$ & $\begin{array}{l}\text { Induces apoptosis and DNA internucleosomal degradation activate } \\
\text { caspase-3 }\end{array}$ \\
$\begin{array}{l}\text { Human acute lymphoblastic leukemia } \\
\text { (Jurkat) [66] }\end{array}$ & $\begin{array}{l}\text { Induces G2/M cell cycle arrest } \\
\text { Induces intrinsic apoptotic pathway via activation of caspase-3 and } \\
\text { caspase-9, cytochrome c release from mitochondria, and PARP cleavage }\end{array}$ \\
$\begin{array}{l}\text { Human chronic myeloid leukemia (KBM-5) } \\
\text { [63] }\end{array}$ & $\begin{array}{l}\text { Induces cytotoxicity } \\
\text { Suppresses TPA-induced superoxide anion generation from NADPH }\end{array}$ \\
$\begin{array}{l}\text { Human acute promyelocytic leukemia } \\
\text { oxidase }\end{array}$ & $\begin{array}{l}\text { Induces G2/M cell cycle arrest in time- and concentration-dependent } \\
\text { manner }\end{array}$ \\
& $\begin{array}{l}\text { Decreases cyclin B1/CDK1 protein level } \\
\text { Induces G2/M cell cycle arrest associated with decline of cyclin B1 } \\
\text { protein and phosphorylation of ATM/Chk1, induced apoptosis via } \\
\text { expression of Fas (CD95)/Fas ligand (CD95L), with the activation of } \\
\text { caspase-8 }\end{array}$ \\
$\begin{array}{l}\text { Human acute promyelocytic leukemia } \\
\text { (NB4) [67] }\end{array}$ & $\begin{array}{l}\text { Antagonizes action of DDT and TCDD by upregulating the expressions } \\
\text { of COX-2 and VEGF mRNA }\end{array}$ \\
Human acute myelocytic leukemia (U937)
\end{tabular}

Human acute lymphoblastic leukemia (MOLT4), human acute lymphocytic leukemia (OKM-2T), and human chronic myelocytic leukemia (K562 and KT-1) [67]

Human peripheral blood multiple myeloma (U266) [68]

Murine lymphoid neoplastic (P-388D1) [69]

Murine acute myelocytic leukemia (WEHI-3B) [70]

Normal human umbilical vein endothelial cell (HUVEC) [67]

Normal human primary mononuclear cells (PBMCs) [71, 72]

Mice thymocytes and splenocytes human PBMC [73]

Human peripheral blood lymphocytes (PBL) Al [74]

Lymphoblastoid (Raji) cells

Human monocyte-like cells (THP-1) [75]

Normal murine macrophages 9RAW264.7) [68]

Immortalized mouse embryonic fibroblasts (SV40) [76]

Human whole blood [31]

No cytotoxicity at concentration of $10 \mu \mathrm{M}$

\section{Suppresses CXCR4 expression}

Causes DNA fragmentation and growth inhibition

Induces $\mathrm{G} 2 / \mathrm{M}$ cell cycle arrest and apoptosis

Does not inhibit proliferation at concentration of $10 \mu \mathrm{M}$

No cytotoxicity $(1-100 \mu \mathrm{g} / \mathrm{mL})$

Cytotoxic at high doses $(40-80 \mu \mathrm{M})$

Stimulates time- and dose-dependent proliferation of mice cells and human PBMC

Upregulates human cytokine (interleukin, IL-2 and IL-12) immunomodulatory

Cytotoxic but not clastogenic at 40 and $80 \mu \mathrm{M}$,

Does not induce chromosomal aberration and micronuclei formation

Suppresses tumor promoter 12-O-tetradecanoylphorbol 13-acetate-

(TPA-) induced activation of Epstein-Barr virus

Suppresses TPA-induced LOX-1 mRNA expression

Attenuates expression of SR-A, SR-PSOX, and CD-36 and led to block

DiI-AcLDL uptake

Inhibits AP-1 and NF- $\kappa$ B transcriptional activity

Markedly diminishes inducible nitric oxide synthase (iNOS) and cyclooxygenase (COX)-2 expression

Suppresses free radical generation and inhibits tumor necrosis factor (TNF) $-\alpha$ release

Induces phase II drug metabolizing enzymes GSTP1 and NQO1 mRNA expressions

Not cytotoxic

Inhibits platelet aggregation induced by arachidonic acid (AA), collagen, and ADP 
TABle 2: Continued.

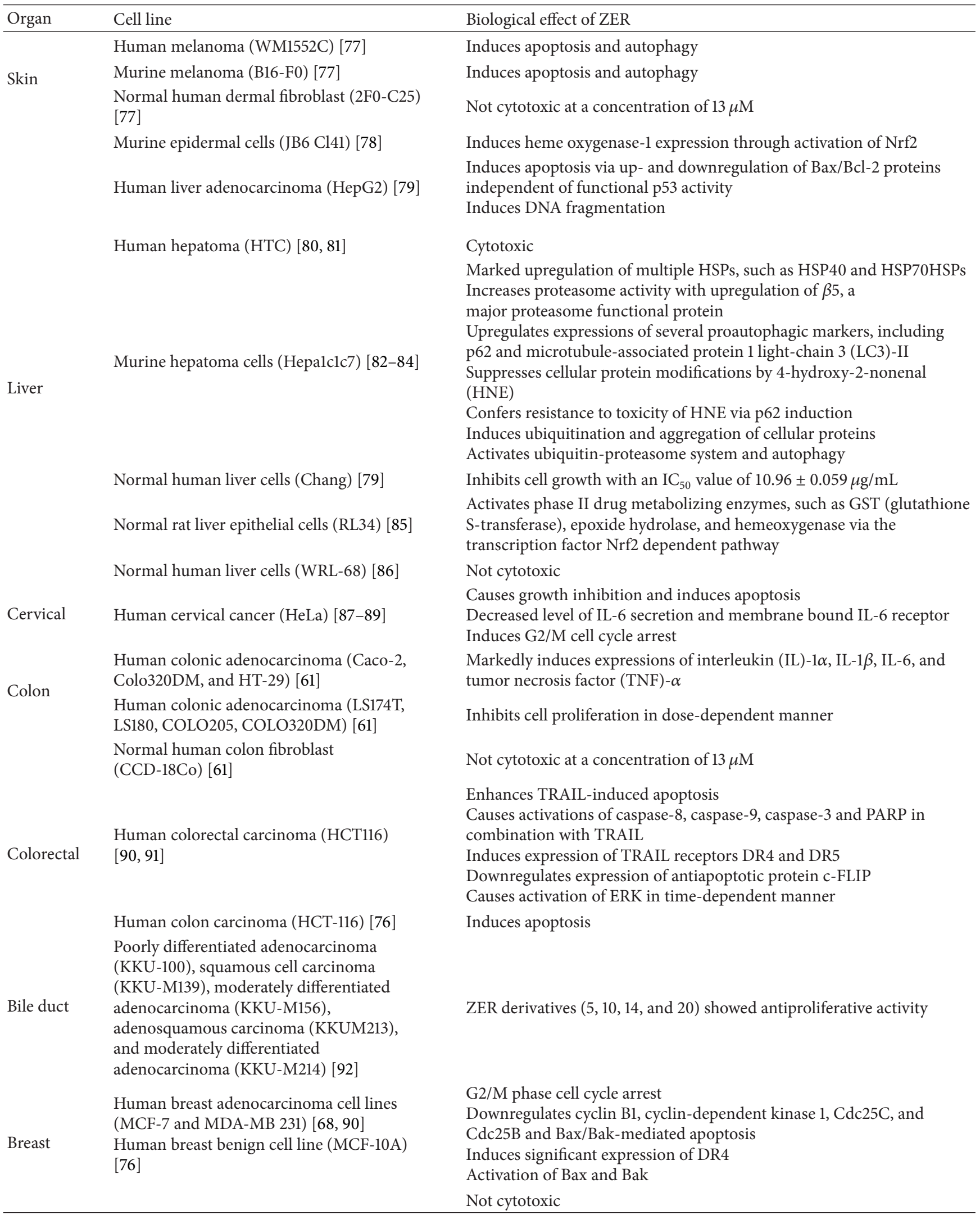


TABle 2: Continued.

\begin{tabular}{|c|c|c|}
\hline Organ & Cell line & Biological effect of ZER \\
\hline \multirow[t]{4}{*}{ Ovarian } & Human ovarian cancer (Caov-3) [59] & $\begin{array}{l}\text { Causes growth inhibition and induces apoptosis } \\
\text { Decreases level of IL- } 6 \text { secretion and membrane bound IL-6 receptor } \\
\text { Induces G2/M cell cycle arrest }\end{array}$ \\
\hline & $\begin{array}{l}\text { Normal Chinese hamster ovarian cells } \\
\text { (AS52) [61] }\end{array}$ & $\begin{array}{l}\text { Suppresses tumor promoter } 12-\mathrm{O} \text {-tetradecanoylphorbol-13-acetate- } \\
\text { (TPA-) induced superoxide anion }\left(\mathrm{O}_{2}^{-}\right) \text {generation from xanthine } \\
\text { oxidase }(\mathrm{XO})\end{array}$ \\
\hline & $\begin{array}{l}\text { Normal Chinese hamster ovary cells }(\mathrm{CHO}) \\
\text { [93] }\end{array}$ & $\begin{array}{l}\text { High concentrations produce genotoxic and cytotoxic effects } \\
(40-80 \mu \mathrm{M})\end{array}$ \\
\hline & Human pancreatic carcinoma $(\mathrm{PaCa})[94]$ & $\begin{array}{l}\text { Novel inhibitor of Jak2/Stat3, which inhibits promigratory gene } \\
\text { expression, growth, and migration of pancreatic cancer cells }\end{array}$ \\
\hline \multirow[t]{3}{*}{ Pancreatic } & $\begin{array}{l}\text { Human pancreatic cancer (PANC-28, MIA } \\
\text { PaCa-2, and AsPC-1) [64] }\end{array}$ & Inhibits CXCL12-induced invasion of pancreatic tumor cells \\
\hline & $\begin{array}{l}\text { Human pancreatic carcinoma (PANC-1 and } \\
\text { SW1990) [95] }\end{array}$ & Time-dependent inhibition of cell viability induces apoptosis \\
\hline & Human pancreatic carcinoma $(\mathrm{PaCa})[96]$ & $\begin{array}{l}\text { Inhibits } \mathrm{PaCa} \text {-associated angiogenesis through the inhibition of NF- } \kappa \mathrm{B} \\
\text { and NF- } \kappa \mathrm{B} \text {-dependent proangiogenic gene products }\end{array}$ \\
\hline \multirow[t]{3}{*}{ Lung } & $\begin{array}{l}\text { Human nonsmall cell lung carcinoma } \\
\text { (H1299 cells) }[63,90]\end{array}$ & $\begin{array}{l}\text { Enhances TNF-induced cytotoxicity and potentiates apoptosis } \\
\text { Inhibits TNF-induced I } \kappa \text { B } \alpha \text { protein degradation and phosphorylation } \\
\text { Inhibits TNF-induced phosphorylation of p } 65 \text { protein } \\
\text { Suppresses TNF-induced invasion activity }\end{array}$ \\
\hline & $\begin{array}{l}\text { Human small cell lung carcinoma } \\
\text { (NCI-H187) [97] }\end{array}$ & $\begin{array}{l}\text { Inhibits monomeric form of the HSP } 27 \text { protein } \\
\text { ZER derivative (parent alcohol 8) induces strong cytotoxicity }\end{array}$ \\
\hline & $\begin{array}{l}\text { Human embryonic kidney carcinoma cell } \\
\text { line (A293 cells) [63] }\end{array}$ & Inhibits cell growth \\
\hline \multirow[t]{3}{*}{ Kidney } & Bovine normal kidney cell line (MDBK) [79] & Inhibits cell growth with an $\mathrm{IC}_{50}$ value of $10.02 \pm 0.03 \mu \mathrm{g} / \mathrm{mL}$ \\
\hline & $\begin{array}{l}\text { Human kidney embryonic cells (HEK 293) } \\
\text { [98] }\end{array}$ & $\begin{array}{l}\text { ZER derivative (parent alcohol 8) could protect irradiation induced cell } \\
\text { apoptosis and DNA damage, at least partly, via activation of } \\
\text { Keap1/Nrf2/ARE pathway }\end{array}$ \\
\hline & $\begin{array}{l}\text { Normal African green monkey kidney cells } \\
\text { (Vero) [97] }\end{array}$ & Nonsignificant cytotoxicity with IC50 of $30 \mu \mathrm{M}$ \\
\hline \multirow[t]{2}{*}{ Brain } & $\begin{array}{l}\text { Human brain malignant glioma (GBM8401) } \\
\text { [99] }\end{array}$ & $\begin{array}{l}\text { Induces human glioblastoma multiforme cell apoptosis via inhibition of } \\
\text { the IKK } \alpha \text {-Akt FOXO1 cascade and activation of caspase- } 3\end{array}$ \\
\hline & $\begin{array}{l}\text { Human brain malignant glioma (U87MG) } \\
\text { [99] }\end{array}$ & Significantly decreases cell viability at the concentration of 30 and $50 \mu \mathrm{M}$ \\
\hline \multirow[t]{2}{*}{ Prostate } & Human adenocarcinoma (DU145) [90] & $\begin{array}{l}\text { Induces cytotoxicity and significant PARP cleavage } \\
\text { Effectively blocks Jak2/STAT3-mediated signaling pathways } \\
\text { Induces nonsignificant expression of DR4 }\end{array}$ \\
\hline & Human adenocarcinoma (PC3) [90] & Induces nonsignificant expression of DR4 \\
\hline Stomach & Human gastric adenocarcinoma (AGS) [100] & $\begin{array}{l}\text { Inhibits tumor angiogenesis via reduction of VEGF production and } \\
\text { NF- } \kappa \text { B activity }\end{array}$ \\
\hline Oral & Human oral cancer $(\mathrm{KB})[97]$ & ZER derivative (parent alcohol 8) induces strong cytotoxicity \\
\hline \multirow[t]{2}{*}{ Headand neck } & $\begin{array}{l}\text { Human squamous cell carcinomas (SCC4) } \\
\text { [64] }\end{array}$ & Suppresses CXCR4 expression and cancer invasion and metastasis \\
\hline & $\begin{array}{l}\text { Human squamous cell carcinoma } \\
\text { (LICR-LONHN5) [63] }\end{array}$ & $\begin{array}{l}\text { Inhibits activation of NF- } \kappa \mathrm{B} \text { and NF- } \kappa \mathrm{B} \text { regulated } \\
\text { gene expression } \\
\text { Suppresses } \mathrm{I} \kappa \mathrm{B} \alpha \text { kinase activity, phosphorylation, and degradation } \\
\text { Suppresses p } 65 \text { phosphorylation, nuclear translocation, and acylation }\end{array}$ \\
\hline Pharynx & $\begin{array}{l}\text { Human squamous cell carcinoma }(\mathrm{FaDu}) \\
{[63]}\end{array}$ & $\begin{array}{l}\text { Inhibits NF- } \kappa \mathrm{B} \text { and } \mathrm{I} \kappa \mathrm{B} \alpha \text { kinase activation } \\
\text { Suppresses antiapoptotic and metastatic gene expression } \\
\text { Upregulates apoptosis and downregulates cancer invasion }\end{array}$ \\
\hline
\end{tabular}


TABLE 2: Continued.

\begin{tabular}{|c|c|c|}
\hline Organ & Cell line & Biological effect of ZER \\
\hline Bone & Mouse macrophage (RAW 264.7) [68] & $\begin{array}{l}\text { Inhibits RANKL-induced NF- } \kappa \text { B activation through inhibition of } \\
\text { activation of IKBA kinase, IKBA phosphorylation, and IKBA } \\
\text { degradation } \\
\text { Suppresses RANKL-induced differentiation of an osteoclast precursor } \\
\text { cells to osteoclasts } \\
\text { Inhibits osteoclastogenesis induced by RANKL and tumor (RAW264.7) } \\
\text { cells after incubation in the presence of MDA-MB-231 cells or U266 cells } \\
\text { for } 24 \text { h, then exposed to ZER for } 5 \text { days, and finally stained for TRAP } \\
\text { expression) } \\
\text { Potential therapeutic agent for osteoporosis and cancer-associated bone } \\
\text { loss }\end{array}$ \\
\hline
\end{tabular}

ZER [110]. Recently, it was found that ZER induces heme oxygenase-1 expression in female HR-1 hairless mouse skin and cultured murine epidermal (JB6 Cl4) cells, through the activation of Nrf2 [78]. More recently, ZER was found to induce apoptosis and autophagy in human (WM1552C) and murine (B16-F0) melanoma cell lines [128]. Zerumbone also significantly reduced tumor mass and lung metastasis in B16F0 bearing C57 BL/6 male mice through the activation of Akt and MAPK and suppression of NF- $\kappa$ B activation [77].

3.3. Liver Cancer. Zerumbone was also found to inhibit the proliferation of nonmalignant Chang liver cell line [129], while being innocuous to the normal human liver (WRL-68) cells [86]. DNA fragmentation and apoptosis induced by ZER is by way of up- and downregulation of $\mathrm{Bax} / \mathrm{Bcl}-2$ proteins independent of functional p53 activity in the liver adenocarcinoma (HepG2) cell lines. In vivo, ZER inhibits diethyl nitrosamine (DEN) and dietary 2acetylaminofluorene- (AAF-) induced Sprague Dawley rat hepatocarcinogenesis. This effect was suggested to be through the reduction of oxidative stress, inhibition of cancer cell proliferation, and induction of mitochondria-regulated apoptosis of liver cancers [105].

3.4. Cervical Cancer. Zerumbone is known to exhibit an antiproliferative effect on human cervical cancer (HeLa) cell line [87]. In diethylstilboestrol- (DES-) induced mice cervical interepithelial neoplasia (CIN), ZER caused overexpression of proapoptotic protein, Bax $[88,130]$.

When ZER and cisplatin were used in combination, the cervical cancer in BALB/c mice was suppressed through the modulation of serum interleukin-6 [131]. One experiment was conducted on pregnant $\mathrm{BALB} / \mathrm{c}$ rats treated with DES to develop cervical intraepithelial neoplasia. When the progenies were treated with different doses of ZER, histological examination revealed that ZER had inhibited the cervical dysplasia from developing into more severe dysplasia [89].

3.5. Colon Cancer. Zerumbone was shown to inhibit the proliferation of human colonic adenocarcinoma (LS174T, LS180, COLO205, and COLO320DM) cell lines in a dosedependent manner, while the growth of normal human colon
(CCD-18Co) fibroblasts and normal human dermal (2F0C25) cells was less affected [90, 110]. The effect of ZER on human colorectal cancer (HCT116) cells was via potentiation of TRAIL-induced apoptosis $[90,91]$ as indicated by the expression of TRAIL death receptor (DR) 4 and 5. The subsequent effects were activations of caspase-8, caspase9, and caspase- 3 and PARP and downregulation antiapoptotic protein c-FLIP expression and activation of ERK in a time-dependent manner. The RT-PCR assay showed that ZER markedly induced the expressions of IL- $1 \alpha$, IL- $1 \beta$, IL6 , and TNF- $\alpha$ in human colon adenocarcinoma (Caco-2, Colo320DM, and HT-29) cell lines, in concentration- and time-dependent manners [110]. Developing azoxymethane(AOM-) induced rat colonic aberrant crypt foci (ACF) in male F344 rat can be significantly inhibited by ZER treatment through suppression of COX-2 expression, cell spreading activity of colonic mucosa, and induction of phase II detoxification enzymes [104]. Similarly, using ACF as a preneoplastic marker, ZER was shown to suppress AOM-induced colon cancer in male Sprague Dawley rats [101]. Zerumbone inhibited the multiplicity of colonic adenocarcinoma induced by AOM, potentiated apoptosis, and suppressed NF- $\kappa \mathrm{B}$ and HO-1 expressions in male ICR mice [102].

3.6. Bile Duct Cancer. Amine 5 derived from ZER showed potent antiproliferative activity against cholangiocarcinoma (CCA) cell line and poorly differentiated adenocarcinoma (KKU-100). However, amine 5 and other ZER derivatives (10, 14, and 20) (Figure 4) showed lesser cytotoxicity toward other CCA cell lines including squamous (KKU-M139) cell carcinoma, moderately differentiated adenocarcinoma (KKUM156), adenosquamous carcinoma (KKUM213), and moderately differentiated adenocarcinoma (KKU-M214) [92].

3.7. Breast Cancer. In breast cancers, ZER caused G2/M phase cell cycle arrest associated with downregulation of cyclin B1, Ddk1, Cdc25C, and Cdc25B and Bax/Bakmediated apoptosis in human breast cancer (MDA-MB-231 and MCF-7) cells and retarded growth of MDA-MB-231 xenografts in vivo [76]. In addition, its derivative, parent alcohol $8(2 E, 6 Z, 10 E)-13$-Hydroxy-2,9,9-trimethylcycloundeca2,6,10-trienone (Figure 5(a)) significantly displayed antiproliferative effect towards human breast cancer (MCF-7) cell 
TABLE 3: In Vivo biological effects of zerumbone.

\begin{tabular}{|c|c|c|c|}
\hline Organ & Animal model & ZER route & Biological effect of ZER \\
\hline \multirow[t]{2}{*}{ Cervix } & $\begin{array}{l}\text { Female BALB/c mice } \\
{[88,89]}\end{array}$ & Intraperitoneal injection & $\begin{array}{l}\text { Suppresses cervical intraepithelial neoplasia in female } \\
\text { Balb/c mice prenatally exposed to diethylstilbestrol (DES) } \\
\text { Reduces the expression of cell proliferation marker PCNA } \\
\text { in dose dependent manner } \\
\text { Causes overexpression of proapoptotic protein Bax } \\
\text { Suppresses Bcl-2 specific mRNA expression } \\
\text { Inhibits progression of cervical dysplasia from becoming } \\
\text { more severe dysplasia (CIN 3) and suppresses level of } \\
\text { serum IL-6 }\end{array}$ \\
\hline & $\begin{array}{l}\text { Male Sprague Dawley } \\
\text { rats [101] }\end{array}$ & Oral dose & $\begin{array}{l}\text { Suppresses azoxymethane- (AOM-) induced colon cancer } \\
\text { using aberrant crypt foci (ACFs) as a preneoplastic marker }\end{array}$ \\
\hline \multirow{3}{*}{ Colon } & Male ICR mice [102] & Oral dose & $\begin{array}{l}\text { Inhibits multiplicity of colonic adenocarcinomas induced } \\
\text { by azoxymethane (AOM) } \\
\text { Suppresses colonic inflammation in dose-dependent } \\
\text { manner } \\
\text { Inhibits cancer proliferation, potentiates apoptosis, and } \\
\text { suppresses NF- } \kappa \text { B and HO-1 expressions }\end{array}$ \\
\hline & $\begin{array}{l}\text { Female ICR mice } \\
{[103]}\end{array}$ & Oral dose & $\begin{array}{l}\text { Suppresses acute ulcerative colitis (UC) induced by } \\
\text { dextran sodium sulfate (DSS) } \\
\text { Significantly lowers levels of inflammatory biomarkers } \\
\text { IL-1 } \beta \text {, TNF- } \alpha \text {, and PGE } \text { in colonic mucosa }_{2} \\
\text { Suppresses expression of inflammatory cytokines, TNF, } \\
\text { and IL- } 1 \beta \text { in LPS/IFN- } \gamma\end{array}$ \\
\hline & Male F344 rats [104] & Oral dose & $\begin{array}{l}\text { Reduces development AOM-induced colonic aberrant } \\
\text { crypt foci } \\
\text { Reduces expression of COX-2 and prostaglandins in } \\
\text { colonic mucosa } \\
\text { Reduces number of AgNORs in colonic crypt cell nuclei }\end{array}$ \\
\hline \multirow{4}{*}{ Liver } & $\begin{array}{l}\text { Male Sprague Dawley } \\
\text { rats [105] }\end{array}$ & Intraperitoneal injection & $\begin{array}{l}\text { Protects rat liver from carcinogenic effects of DEN and } \\
\text { AAF } \\
\text { Lowers serum ALT, AST, AP, and AFP concentrations } \\
\text { Lowers concentration of GSH in hepatic tissue } \\
\text { Lowers expression of PCNA in the rat liver } \\
\text { Increases Bax and decreases Bcl-2 protein expression in } \\
\text { the liver }\end{array}$ \\
\hline & $\begin{array}{l}\text { Male Sprague Dawley } \\
\text { rats }[106,107]\end{array}$ & Oral dose & $\begin{array}{l}\text { Suppresses fatty liver formation induced by overdosage of } \\
\text { ethanol } \\
\text { Prevents necrosis of liver tissues after administration of } \\
\text { overdosage of paracetamol } \\
\text { Reduces levels of liver ALT, AST, and ALP at } 24 \mathrm{~h} \text { after } \\
\text { administration of overdosage of paracetamol }\end{array}$ \\
\hline & $\begin{array}{l}\text { Male golden Syrian } \\
\text { hamsters [108] }\end{array}$ & Oral dose & $\begin{array}{l}\text { Attenuates nonalcoholic fatty liver disease } \\
\text { Improves insulin sensitivity, decreases lipogenesis, and } \\
\text { increases lipid oxidation }\end{array}$ \\
\hline & $\begin{array}{l}\text { Male Sprague Dawley } \\
\text { rats [82] }\end{array}$ & Oral dose & $\begin{array}{l}\text { Upregulates heat shock protein expressions in the liver } \\
\text { Confers thermoresistant phenotype }\end{array}$ \\
\hline Lung & Female A/J mice [102] & Oral dose & $\begin{array}{l}\text { Significantly inhibits multiplicity of lung adenomas } \\
\text { induced by } \\
4 \text {-(Nmethyl-N-nitrosamino)-1-(3-pyridyl)-1-butanone } \\
\text { (NNK) } \\
\text { Inhibits cancer proliferation, potentiates apoptosis, and } \\
\text { suppresses NF- } \mathrm{B} \text { and HO-1 expressions }\end{array}$ \\
\hline
\end{tabular}


TABle 3: Continued.

\begin{tabular}{|c|c|c|c|}
\hline Organ & Animal model & ZER route & Biological effect of ZER \\
\hline & $\begin{array}{l}\text { Female Sprague } \\
\text { Dawley rats [109] }\end{array}$ & Intraperitoneal injection & $\begin{array}{l}\text { Inhibits tumor growth via Wnt pathway in LA-7 bearing } \\
\text { rats }\end{array}$ \\
\hline \multirow[t]{2}{*}{ Breast } & $\begin{array}{l}\text { Female severe } \\
\text { combined immune } \\
\text { deficient (SCID) mice } \\
{[76]}\end{array}$ & Intraperitoneal injection & $\begin{array}{l}\text { Retards growth of orthotopic MDA-MB-231 xenografts in } \\
\text { association with apoptosis induction and suppression of } \\
\text { cell proliferation (Ki-67 expression) }\end{array}$ \\
\hline & $\begin{array}{l}\text { Female } \mathrm{BALB} / \mathrm{c} \mathrm{nu} / \mathrm{nu} \\
\text { mice }[68 \text { ] }\end{array}$ & Intraperitoneal injection & $\begin{array}{l}\text { Decreases osteolytic bone metastasis in MDA-MB- } 231 \\
\text { bearing athymic nude mice dose dependently }\end{array}$ \\
\hline \multirow[t]{3}{*}{ Blood } & $\begin{array}{l}\text { WEHI-3B bearing } \\
\text { male BALB/c mice } \\
{[70]}\end{array}$ & Oral dose & $\begin{array}{l}\text { Induces apoptosis via the mitochondrial intrinsic pathway } \\
\text { Increases expression of Bax, Cyt-c, and PARP and } \\
\text { decreases the expression of Bcl-2 }\end{array}$ \\
\hline & CDF mice [69] & Intraperitoneal injection & Significantly prolongs life of P-388D1-bearing CDF mice \\
\hline & $\begin{array}{l}\text { C57 BL/6 male mice } \\
{[77]}\end{array}$ & Intraperitoneal injection & $\begin{array}{l}\text { Significantly reduces tumor mass and lung metastasis in } \\
\text { B16-F0 bearing mice through the activation of Akt and } \\
\text { MAPK and inhibition of NF- } \kappa \text { B activity }\end{array}$ \\
\hline \multirow[t]{2}{*}{ Skin } & ICR mice $[110]$ & Topical application & $\begin{array}{l}\text { Suppresses 7,12-dimethylbenz }[\alpha] \text { anthracene (DMBA) and } \\
\text { TPA-induces initiation and promotion of skin tumor } \\
\text { formation } \\
\text { Enhances expression of antioxidative and phase II } \\
\text { xenobiotics metabolizing enzymes manganese superoxide } \\
\text { dismutase (MnSOD), glutathione peroxidise-1 (GPx-1), } \\
\text { glutathione S-transferase-P1 (GST-P1), and NAD (P) H } \\
\text { quinine oxidoreductase (NQO1) mRNA in the epidermis } \\
\text { Suppresses TPA-induced COX-2 expression and } \\
\text { phosphorylation of ERK1/2 } \\
\text { Suppresses TPA-induced leukocyte maturation and dermal } \\
\text { infiltration as well as activation stages of skin tumors }\end{array}$ \\
\hline & $\begin{array}{l}\text { Female HR-1 hairless } \\
\text { mice [78] }\end{array}$ & Topical application & Induces $\mathrm{HO}-1$ expression through activation of $\mathrm{Nrf} 2$ \\
\hline Paw & Mice [24] & Intraperitoneal injection & $\begin{array}{l}\text { Inhibits carrageenan-induced paw edema dose } \\
\text { dependently } \\
\text { Suppresses granulomatous tissue formation in cotton } \\
\text { pellet-induced granuloma test }\end{array}$ \\
\hline \multirow{3}{*}{ Eye } & & & $\begin{array}{l}\text { Protects mouse cornea from ultraviolet B- (UVB-) } \\
\text { induced inflammatory photokeratitis } \\
\text { Inhibits NF- } \kappa \text { B, iNOS, and TNF- } \alpha \text { expressions }\end{array}$ \\
\hline & ICR mice $[111,112]$ & Oral dose & $\begin{array}{l}\text { Abrogates nuclear translocation of NF- } \kappa \text { B } \\
\text { Reduces malonyldialdehyde (MDA) accumulation and } \\
\text { increases GSH and glutathione reductase levels } \\
\text { Protects mice cornea from UVB-induced cataractogenesis }\end{array}$ \\
\hline & Male Wistar rats [113] & Oral dose & $\begin{array}{l}\text { Suppresses cholecystokinin octapeptide- (CCK-8-) } \\
\text { induced acute pancreatitis } \\
\text { Significantly reduces serum amylase and lipase activities } \\
\text { Reduces cytosolic IL- } 6 \text { and TNF-a and increases cytosolic } \\
\text { Iát'NB } \alpha \text { concentration } \\
\text { Reduces iNOS and } \mathrm{Mn} \text { - and } \mathrm{Cu} / \mathrm{Zn} \text {-superoxide dismutase } \\
\text { activities } \\
\text { Significantly reduces pancreatic weight to body weight } \\
\text { ratio }\end{array}$ \\
\hline
\end{tabular}


TABle 3: Continued.

\begin{tabular}{|c|c|c|c|}
\hline Organ & Animal model & ZER route & Biological effect of ZER \\
\hline \multirow{4}{*}{ Bone } & $\begin{array}{l}\text { Male SPF Wistar rats } \\
{[114]}\end{array}$ & Intravenous injection & $\begin{array}{l}\text { Attenuates severity of acute necrotizing pancreatitis } \\
\text { induced by sodium taurocholate and pancreatitis-induced } \\
\text { hepatic injury, via inhibition of NF- } \kappa \text { B activity and } \\
\text { downregulation of ICAM- } 1 \text { and IL- } 1 \beta \text { expressions }\end{array}$ \\
\hline & $\begin{array}{l}\text { Male Sprague Dawley } \\
\text { rats [115] }\end{array}$ & Oral dose & $\begin{array}{l}\text { Reduces inflammatory process in collagen-induced } \\
\text { osteoarthritis (OA) } \\
\text { Significantly reduces number of major histocompatibility } \\
\text { complex type II cells (MHC) expression in the affected } \\
\text { synovial membrane } \\
\text { Reduces the number of antigen presenting type A cells } \\
\text { presented during arthritis }\end{array}$ \\
\hline & $\begin{array}{l}\text { Male Sprague Dawley } \\
\text { rats }[116,117]\end{array}$ & Oral dose & $\begin{array}{l}\text { Produces chondroprotective effects in MIA-induced knee } \\
\text { osteoarthritis } \\
\text { Improved immunoreactivity of neuropeptides } \\
\text { Improves density of protein gene products (PGP), } \\
\text { calcitonin gene-related peptide (CGRP), and } \\
\text { neuropeptides-Y (NPY) immunoreactive nerve fibers } \\
\text { Reduces the level of PGE } 2 \text { Produces induction of } \\
\text { cytochrome P450 and cytosolic GST }\end{array}$ \\
\hline & Male ICR mice [118] & Intraperitoneal injection & $\begin{array}{l}\text { Produces pronounced antinociception against chemical } \\
\text { models of nociception through L-arginine-nitric } \\
\text { oxide-cGMP-PKC-K+ ATP channel pathways, the TRPV1, } \\
\text { and kinin B2 receptors }\end{array}$ \\
\hline \multirow{6}{*}{ Miscellaneous } & $\begin{array}{l}\text { Male BALB/c mice } \\
{[119]}\end{array}$ & Intraperitoneal injection & $\begin{array}{l}\text { Produces significant peripheral and central antinociceptive } \\
\text { effects when assessed in acetic acid-induced abdominal } \\
\text { writhing and hot-plate test models }\end{array}$ \\
\hline & $\begin{array}{l}\text { Female and male } \\
\text { BALB/c mice }[120]\end{array}$ & Oral dose & $\begin{array}{l}\text { No toxic effects to liver and renal tissues } \\
\text { Does not cause significant change in hematological and } \\
\text { serum biochemical parameters }\end{array}$ \\
\hline & $\begin{array}{l}\text { Female and male ICR } \\
\text { mice }[121]\end{array}$ & Intraperitoneal injection & $\begin{array}{l}\text { Does not cause mortality or change in the general } \\
\text { condition, growth, organ weights, hematology, serum } \\
\text { biochemistry, or histopathology after a single dosage of } \\
500 \mathrm{mg} / \mathrm{kg} \text { or multiple dosage of } \mathrm{f} 5,25 \text {, and } 50 \mathrm{mg} / \mathrm{kg} \text { for a } \\
\text { period of } 28 \text { days }\end{array}$ \\
\hline & $\begin{array}{l}\text { Female Sprague } \\
\text { Dawley rats [122] }\end{array}$ & $\begin{array}{l}\text { Single intraperitoneal } \\
\text { injection }\end{array}$ & $\begin{array}{l}\text { Not toxic to liver and renal tissues at dose of } \\
100-200 \mathrm{mg} / \mathrm{kg} \\
\text { Produces severe renal and hepatic damage at a dose of } \\
500 \mathrm{mg} / \mathrm{kg} \text { with increased serum creatinine, BUN, liver } \\
\text { enzymes (ALT, ALP, and GGT), and MDA concentrations } \\
\text { Does not cause mortality at } 100,200,500 \text {, and } 1000 \mathrm{mg} / \mathrm{kg} \\
\text { Causes } 20 \text { and } 40 \% \text { death for animals receiving } 1500 \text { and } \\
2000 \mathrm{mg} / \mathrm{kg} \text {, respectively } \\
\text { Causes } 100 \% \text { death in animals receiving } 2500 \text { and } \\
3000 \mathrm{mg} / \mathrm{kg}\end{array}$ \\
\hline & $\begin{array}{l}\text { Male Sprague Dawley } \\
\text { rats }[71,74]\end{array}$ & Intraperitoneal injection & $\begin{array}{l}\text { Induces significant increase in the frequency of } \\
\text { micronuclei in polychromatic erythrocytes (PCEs) at dose } \\
1000 \mathrm{mg} / \mathrm{kg} \text { after } 24 \text {-hour injection } \\
\text { Inhibits cell proliferation and causes cytotoxicity in the rat } \\
\text { bone marrow }\end{array}$ \\
\hline & $\begin{array}{l}\text { Female Sprague } \\
\text { Dawley rats [123] }\end{array}$ & Intraperitoneal injection & $\begin{array}{l}\text { Beneficial in cisplatin-induced renal dysfunction, toxicity, } \\
\text { and organ damage via preservation of antioxidant } \\
\text { glutathione and prevention of lipid peroxidation } \\
\text { Attenuates cisplatin, decreases renal GSH, and increased } \\
\text { MDA levels }\end{array}$ \\
\hline
\end{tabular}


TABLE 3: Continued.

\begin{tabular}{|c|c|c|c|}
\hline Organ & Animal model & ZER route & Biological effect of ZER \\
\hline & $\begin{array}{l}\text { Male New Zealand } \\
\text { white rabbits [124] }\end{array}$ & Oral dose & $\begin{array}{l}\text { Significantly averts and decreases early atheroma plague } \\
\text { formation and development via reduction in monocytes } \\
\text { and/or macrophages migration, aggregation, and smooth } \\
\text { muscle cells proliferation in rabbits fed on cholesterol-rich } \\
\text { diet } \\
\text { Repairs endothelial dysfunction resulting from } \\
\text { hyperlipidemia in rabbit atherosclerosis model }\end{array}$ \\
\hline & $\begin{array}{l}\text { Male golden Syrian } \\
\text { hamsters [125] }\end{array}$ & Oral dose & $\begin{array}{l}\text { Improves dyslipidemia by modulating the genes } \\
\text { expression involved in the lipolytic and lipogenic } \\
\text { pathways of lipids metabolism } \\
\text { Decreases hepatic mRNA levels of fatty acid synthase, } \\
\text { malic enzyme, sterol-regulatory element binding protein, } \\
\text { and 3-hydroxy-3-methyl-glutaryl-CoA reductase }\end{array}$ \\
\hline & Male Wistar rats [20] & Oral dose & $\begin{array}{l}\text { Ameliorates streptozotocin-induced diabetic nephropathy } \\
\text { (DN) by reducing the hyperglycemia-induced } \\
\text { inflammatory response } \\
\text { Decreases infiltration of macrophages, IL-1, IL- } 6 \text {, and } \\
\text { TNF- } \alpha \text { produced by p38 mitogen-activated protein kinase } \\
\text { activation }\end{array}$ \\
\hline
\end{tabular}

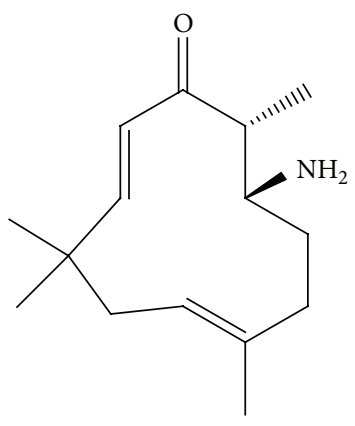

(a)

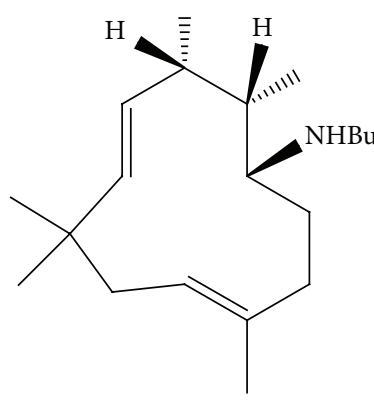

(b)

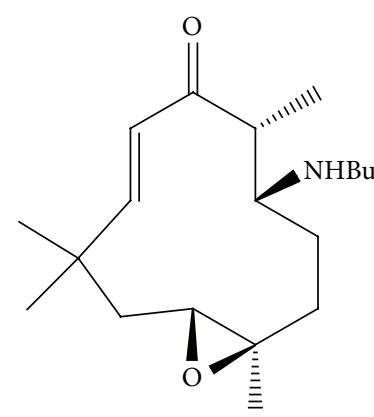

(c)

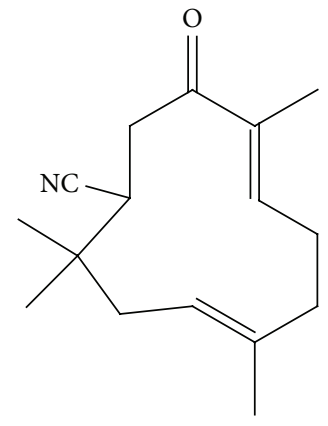

(d)

Figure 4: Zerumbone derivatives. (a) ( \pm )-[6E,10E]-3amino-2,6,9,9-tetramethylcloundeca-6,10-dienone (5), (b) ( \pm )-[6E,10E]-3-butylamino2,6,9,9-tetramethylcloundeca-6,10-dienol (10),(c) ( \pm )-[10E]-3-butylamino-6,7-epoxy-2,6,9,9-tetramethylcloundeca-10-enone (14), and (d) ( \pm )[2E,6E]-10-cyano-2,6,9,9-tetramethylcloundeca-2,6-dienone (20).

line [97]. The inhibition of mammary tumor growth in LA7bearing Sprague Dawley rats was via Wnt/ $\beta$-catenin signaling pathway [109].

3.8. Ovarian Cancer. The antiproliferative effect of ZER towards human ovarian cancer (Caov-3) cell line is dose dependent and time dependent. Zerumbone also effectively suppressed tumor promoter TPA-induced superoxide anion $\left(\mathrm{O}_{2}{ }^{-}\right)$generation from xanthine oxidase (XO) in Chinese hamster ovary (AS52) cells (CHO) [132], while even at high concentrations it does not adversely affect normal cultured $\mathrm{CHO}$ [93].

3.9. Pancreatic Cancer. Zerumbone is a novel inhibitor of Jak2/Stat3, which inhibits promigratory gene expression, growth, and migration of human pancreatic carcinoma (PaCa) [94]. It also inhibits CXCL12-induced spread of pancreatic (PANC-28, MIA PaCa-2, and AsPC-1) tumors [64].
The antipancreatic cancer effect of ZER is facilitated by the inhibition of cancer angiogenesis through the inhibition of $\mathrm{NF}-\kappa \mathrm{B}$ and NF- $\kappa \mathrm{B}$-dependent proangiogenic gene products [96]. The inhibition and apoptosis of human pancreatic carcinoma cell lines (PANC-1 and SW1990) were via p53 signaling pathway [95].

3.10. Lung Cancer. The nonsmall lung adenocarcinoma (H1299) cell can be suppressed by ZER, while its derivative, the parent alcohol $8(2 E, 6 Z, 10 E)-13-H y d r o x y-2,9,9-$ trimethylcycloundeca-2,6,10-trienone, is one of the most potent cytotoxic compounds against human small cell lung carcinoma (NCI-H187) [97]. Zerumbone also effectively inhibited proliferation, multiplicity of lung adenomas induced by NNK, potentiated apoptosis, and suppressed NF$\kappa \mathrm{B}$ and $\mathrm{HO}-1$ expressions in female $\mathrm{A} / \mathrm{J}$ mice [133].

3.11. Renal Cancer. Human embryonic kidney carcinoma (A293) cell [64] and kidney epithelial (MDBK) cell line [129] 


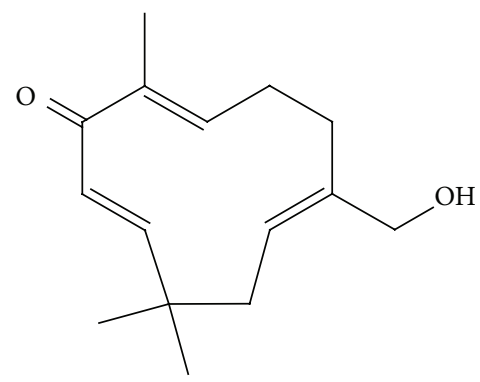

(a)
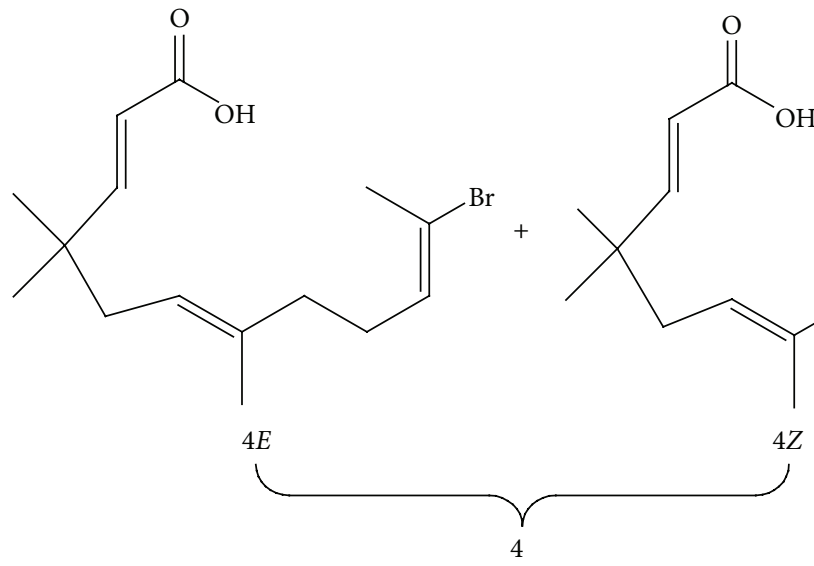

(c)

Figure 5: Zerumbone imidazole and ring opening derivatives. (a) Parent alcohol 8 (2E,6Z,10E)-13-Hydroxy-2,9,9-trimethylcycloundeca-2,6,10trienone, (b) NH0891 ([2E,6E,10E/Z0]-11-bromo-4,4,7-trimethyl-2,6,10-dodecatrienoic acid), and (c) 4 (10E/10Z = 3/2).

proliferation was found to be inhibited by ZER treatment. Zerumbone could also protect irradiation-induced cell apoptosis and DNA damage, partly through the activation of the Keap1/Nrf2/ARE pathway in human kidney embryonic (HEK 293) cells [98]. The ZER derivative, parent alcohol $8(2 E, 6 Z, 10 E)-13$-Hydroxy-2,9,9-trimethylcycloundeca2,6,10-trienone, showed nonsignificant cytotoxicity toward normal monkey kidney (Vero) cell line [97].

3.12. Brain Cancer. Zerumbone can induce human glioblastoma multiforme (GBM8401) cell apoptosis via inhibition of the IKK $\alpha$-Akt FOXO1 cascade [99].

3.13. Prostate Cancer. Zerumbone induced cytotoxicity and significant PARP cleavage in human prostate cancer (DU145) cell line through the inhibition of Jak2/STAT3-mediated signaling pathways [134].

3.14. Gastric Cancer. Zerumbone inhibits tumor angiogenesis in human gastric adenocarcinoma (AGS) cells of via reduction of VEGF production and NF- $\kappa$ B activity [135].

3.15. Oral Cancer. Parent alcohol $8(2 E, 6 Z, 10 E)-13$-Hydroxy2,9,9-trimethylcycloundeca-2,6,10-trienone is one of the most powerful compounds inducing cytotoxicity of human oral cancer $(\mathrm{KB})$ cells [97].
3.16. Head and Neck Cancer. Expression of CXCR4 and invasion and metastasis of human tongue squamous (SCC4) cell carcinoma can occur with ZER treatment [64]. Similarly, ZER inhibited the NF- $\kappa \mathrm{B}$ - and NF- $\kappa \mathrm{B}$-regulated gene expression induced by various carcinogens and inflammatory stimuli, such as TNF, okadaic acid, cigarette smoke condensate, phorbol myristate acetate, and $\mathrm{H}_{2} \mathrm{O}_{2}$. It also suppressed $\mathrm{I} \kappa \mathrm{B} \alpha$ kinase activity, phosphorylation, and degradation and p65 phosphorylation, nuclear translocation, and acylation in human squamous (LICR-LONHN5) cell carcinoma line [63].

3.17. Pharyngeal Cancer. Zerumbone inhibited NF- $\kappa \mathrm{B}$ and $\mathrm{I} \kappa \mathrm{B} \alpha$ kinase, suppressed antiapoptotic and metastatic gene expression, upregulated apoptosis, and inhibits proliferation of human hypopharyngeal carcinoma (FaDu) cells [63].

\section{Anti-Inflammatory Activity}

Zerumbone has been shown to possess anti-inflammatory properties $[25,26]$. Oral ZER treatment suppressed dextran sodium sulfate- (DSS-) induced acute ulcerative colitis (AUC) in female ICR mice. The anti-inflammatory effect of ZER was reflected by the significant lowering of the inflammatory biomarkers, IL-1 $\beta$, TNF- $\alpha$, and PGE2 [103]. In a female ICR mouse ultraviolet B (UVB) photokeratitis and cataractogenesis model, dietary ZER prevented corneal 
damage by inhibiting NF- $\kappa \mathrm{B}$, iNOS, and TNF- $\alpha$ expression with concomitant reduction of malondialdehyde (MDA) and increase of glutathione (GSH) and GSH reductase (GR) levels [111, 112]. Moreover, ZER inhibited iNOS and COX2 expression and release of TNF- $\alpha$ in a mouse macrophage (RAW264.7) cell line treated with lipopolysaccharide (LPS) and IFN- $\gamma$. Zerumbone also inhibited the $\mathrm{NO} / \mathrm{O}_{2}{ }^{-}$generation in inflammatory leukocytes $[61,103]$. Oral feeding of ZER compound reduced the inflammatory process in collagen-induced osteoarthritis (OA) in Sprague Dawley rats. The treatment caused a significant reduction in the number of major histocompatibility complex (MHC) type II cells expressions in the affected synovial membrane and thus reducing accumulation of antigen presenting type A cells in arthritis [115]. In a rat knee osteoarthritis model, induced with monosodium iodoacetate (MIA), oral administration of ZER improved the densities of protein gene products (PGP), calcitonin gene-related peptide (CGRP), and neuropeptidesY (NPY) immunoreactive nerve $[116,117]$.

In male Wistar rats, ZER suppressed cholecystokinin octapeptide- (CCK-8-) induced acute pancreatitis with significant reduction in serum amylase and lipase, cytosolic IL-6, iNOS, Mn- and Cu/Zn-SOD activities, and TNF- $\alpha$ concentration [113]. In these rats ZER treatment attenuates the severity of acute necrotizing pancreatitis and pancreatitisinduced hepatic injury via the inhibition of $N F-\kappa B$ and downregulation of ICAM-1 and IL-1 $\beta$ expressions [114].

\section{Antioxidant Activity}

The antioxidant activity of ZER has been reported to occur through the attenuation of reactive oxygen (RO) and generation of nitrogen species [136]. Thus, it is plausible that the potential of ZER as an agent against cancer-related inflammation may be mediated through its antioxidant activity. The ability of ZER to stimulate phase II detoxification enzymes was determined in the RL34 cells, a normal rat liver epithelial cell line. Induction of phase II enzymes is known to protect cells and tissues against toxicity and chemical carcinogenesis, particularly in the early phase. The effect of ZER on the stimulation of glutathione S-transferase is dose- and timedependent and causes considerable increase in the level of the GSTP1-1 protein. Zerumbone also elicited significant induction in the nuclear localization of $\mathrm{Nrf} 2$, a transcription factor that binds to the antioxidant response element (ARE) of phase II enzyme genes, activating expression of phase II enzyme genes. Among the phase II enzyme involved in the activation are $\gamma$-glutamylcysteine synthetase (GCS), glutathione peroxidase (GPx), and HO-1. These enzyme systems, through their conjugation reactions, play important roles in the metabolic inactivation of pharmacologically active substances, thus minimizing cell damage [85].

\section{Immunomodulatory Activity}

Zerumbone has effect on the proliferation, cell cycle progression, and induction of cytokine (IL-2 and IL-12) of immune cells in vitro. This was shown by the proliferation of ICF mice thymocytes and splenocytes and human peripheral blood mononuclear cells (PBMC). Using flow cytometry, ZER treatment was shown to cause the highest population of PBMC to enter $\mathrm{G} 2 / \mathrm{M}$ phase [73]. This study showed prominent upregulation of IL-2 and IL-12 in activated lymphocytes after ZER treatment.

\section{Other Biomedical Properties of Zerumbone}

7.1. Hepatoprotective Activity. Zerumbone was shown to have hepatoprotective properties in ethanol-induced liver injury in male Sprague Dawley rats, while ZER pretreatment extensively reduced fatty liver development in these rats [106]. Similar ZER has healing effects in paracetamol-induced hepatotoxicity in male Sprague Dawley rats as indicated by the corresponding reductions of alanine aminotransferase (ALT), aspartate aminotransferase (AST), and alkaline phosphatase (ALP) blood concentrations in the treated rats [87].

7.2. Antiatherosclerotic Activity. Zerumbone is a phytochemical with potential for the regulation of atherosclerosis because it suppresses TPA-induced oxidized low density lipoprotein (LDL) receptor-1 (LOX-1) mRNA expression in THP-1 human monocyte-like cells and in differentiated colonic adenocarcinoma (Caco-2) cells. A key event in the development of atherosclerosis is the unregulated uptake of oxidized LDL via scavenger receptors (SR), which are integral membrane proteins. Zerumbone reduces the expression of several subclasses of the macrophage SR such as SR-A, SRPSOX, and CD36, leading to the inhibition of uptake of DiI-acLDL, a modified LDL. Downregulation in the expression of SR by ZER was postulated to be partly attributed to the inhibition of transcriptional activities of activator protein-1 and NF- $\kappa \mathrm{B}$ [75]. In rabbits fed cholesterol-rich diet, oral ZER treatment significantly decreased or averted early atheroma plague formation and development via reduction in monocytes and/or macrophages migration, aggregation, and smooth muscle cells proliferation. In a rabbit atherosclerosis model, ZER was also shown to repair endothelial dysfunction [124].

7.3. Antinociceptive Activity. Significant antinociceptive effects of intraperitoneal ZER were observed in adult male $\mathrm{BALB} / \mathrm{c}$ mice. The results of this study indicated that ZER possesses considerable marginal and central antinociceptive effects at various dosages [27]. The production of antinociception in the mice model suggests significant involvement of L-arginine-nitric oxide-cGMPPKC-K+ ATP channel pathways, the TRPV1 and kinin B2 receptors [118].

7.4. Antimicrobial Activity. Zerumbone and its derivatives such as $410 E / 10 Z=3 / 2$ and NH0891 (Figures 5(b) and $5(c))$ were found to be selective inhibitors of gram-positive bacteria, Bacillus subtilis 168 growth. It was suggested that the new haloolefinic acids synthesized by the cleavage of the C1-C2 bone of ZER inhibits growth of gram-positive bacteria by inhibiting YycG histidine kinase $[137,138]$. Zerumbone 


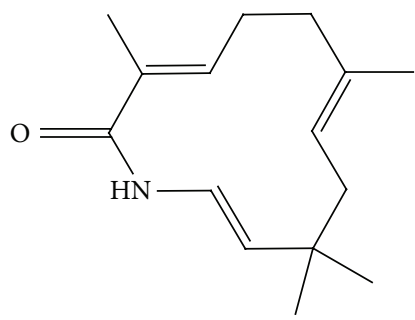

(a)

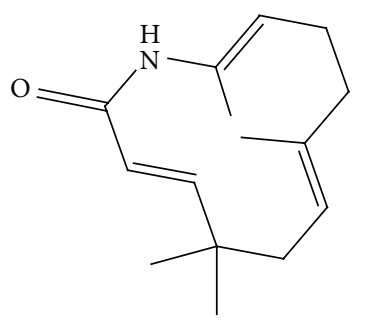

(b)
Figure 6: Zerumbone derivatives. (a) Azazerumbone 1, and (b) azazerumbone 2 .

also inhibits Salmonella choleraesuis, a gram-positive bacteria while not affecting the viability of Escherichia coli [139]. Similarly, ZER and its synthetic analogues (azazerumbone 1 and azazerumbone 2) (Figure 6) exhibited strong protection against sodium azide-induced mutagenicity of Salmonella typhimurium (TA 98 and TA 1531) strains. Among the bacteria tested, Bacillus cereus was most sensitive to these analogues [140].

Other antipathogen effects of ZER include inhibition of human immunodeficiency virus (HIV) activity [33] and antifungal activity towards Rhizoctonia solani, the dampingoff pathogen [52].

Zerumbone was reported to have antimalarial activities by inhibiting propagation of Plasmodium falciparum [141]. Exposure of the nematode Caenorhabditis elegans to ZER increased expression of HSP16.41 mRNA, suggesting that ZER can increase the survival of nematodes after heat-shock treatment.

In lipid metabolism, ZER improved dyslipidemia by modulating expression of genes involved in the lipolytic and lipogenic pathways of a diet-induced hyperlipidemic animal model [125]. This study suggests that ZER is beneficial to patients with hypercholesterolemia and hypertriglyceridemia. Another study showed that ZER attenuated nonalcoholic fatty liver disease, improved insulin sensitivity, decreased lipogenesis, and increased lipid oxidation in male golden Syrian hamster [108]. Zerumbone also seems to be beneficial in alleviating symptoms of renal dysfunction. Treatment of female Sprague Dawley rats with cisplatininduced renal disease with ZER had reduced toxicity and organ damage via the preservation of antioxidant glutathione and prevention of lipid peroxidation [123].

Zerumbone induces genotoxic and cytotoxic effects on cultured human peripheral blood lymphocytes [71], $\mathrm{CHO}$ cells, and rat bone marrow polychromatic erythrocytes (PCEs) [74, 142]. In fact highly concentrated ZER could cause substantial increase in the frequency of micronuclei in these cells. This study suggests that there are safety issues in the development of ZER as a potential therapeutic compound, because very high doses of ZER may produce adverse effects.

Finally, there is evidence that ZER may be useful in the treatment of Alzheimer's disease. This was suggested by a recent study that showed ZER inhibits acetylcholinesterase [143]. The enzymolytic effect of ZER towards AChE (acetylcholinesterase) could be the basis for the development of ZER in the treatment of Alzheimer's disease.

\section{Discussion}

Many natural compounds possess various and significant biological activities. Thus traditionally these compounds are included in the diet of many Asian societies because they are not only nontoxic but also beneficial to health [144]. However, there is a dearth of scientific and clinical evidence supporting effectiveness, usefulness, and safety of herbal compound used in traditional medicine. Because of lacking evaluation of the toxicity and negative reactions of medicinal herbs, the use of natural compounds may prove unsafe.

Malaysia, with its tropical rainforests, is blessed with high biodiversity. The Malaysian forest is an enormous potential source of chemicals and metabolites that can be developed into new agents or novel drugs for treatment of chronic diseases [145]. The jungles of South East Asia have provided more than 6,500 different plants that have been used in the treatment of various illnesses particularly cancers [146]. The South East Asians seemed to have lower risks for development of cancers including colon, gastrointestinal, prostate, and breast cancers compared to Westerners [147]. It is probably the practice of regular consumption of natural plant products that contributes to the lower incidence of these debilitating diseases in the South East Asians.

Recently, in our laboratory, ZER was made soluble by incorporating in the cyclodextrin complex. The production of the ZER-cyclodextrin complex enabled ZER to be formulated as an encapsulated natural compound ready for use, either as an injectable solution or delivered orally as an anticancer product $[148,149]$. The usefulness of encapsulated ZER complex as potential anticancer is worth future exploration through preclinical and human clinical trials to determine efficacy and safety of the product for human use. More recently we also encapsulated ZER into a nanostructured lipid carrier (NLC) using the high pressure homogenization (HPH) technique. The physiochemical properties, entrapment efficiency, storage stability, in vitro release, and cytotoxic effect of this formulation against human acute lymphocytic leukemia (Jurkat) cell line were studied and showed promising results. Our study also showed that ZER-loaded NLC can be further developed as a drug delivery system for cancer therapy $[23,66]$. This new approach to using a natural metabolite in innovative delivery systems would seemingly be an alternative and new approach in the treatment of cancers [72].

This review has clearly indicated that ZER from Zingiber zerumbet Smith possesses various beneficial in vitro and in vivo biological activities. The findings from all the researches reviewed in this paper are conclusive evidences that ZER is a strong potential candidate for anticancer compound. There is need to conduct animal studies and human clinical trials to ascertain the efficacy, usefulness, and safety of this compound as an intended pharmaceutical drug.

\section{Conflict of Interests}

The authors declare that there is no conflict of interests regarding the publication of this paper. 


\section{References}

[1] K. H. Kwon, A. Barve, S. Yu, M.-T. Huang, and A.-N. T. Kong, "Cancer chemoprevention by phytochemicals: potential molecular targets, biomarkers and animal models," Acta Pharmacologica Sinica, vol. 28, no. 9, pp. 1409-1421, 2007.

[2] K. Larsen, H. Ibrahim, S. H. Khaw, and L. G. Saw, Gingers of Peninsular Malaysia and Singapore, Natural History Publications, Borneo, Island, 1999.

[3] N. J. Yob, S. M. Jofrry, M. M. R. Affandi, L. K. Teh, M. Z. Salleh, and Z. A. Zakaria, "Zingiber zerumbet (L.) Smith: a review of its ethnomedicinal, chemical, and pharmacological uses," Evidence-based Complementary and Alternative Medicine, vol. 2011, Article ID 543216, 12 pages, 2011.

[4] S. Basak, G. C. Sarma, and L. Rangan, "Ethnomedical uses of Zingiberaceous plants of Northeast India," Journal of Ethnopharmacology, vol. 132, no. 1, pp. 286-296, 2010.

[5] K. K. Rout, S. K. Mishra, and J. Sherma, "Development and validation of an HPTLC method for analysis of zerumbone, the anticancer marker from Zingiber zerumbet," Acta Chromatographica, vol. 21, no. 3, pp. 443-452, 2009.

[6] N. I. Bhuiyan, J. U. Chowdhury, and J. Begum, "Chemical investigation of the leaf and rhizome essential oils of Zingiber zerumbet (L.) Smith from Bangladesh," Bangladesh Journal of Pharmacology, vol. 4, no. 1, pp. 9-12, 2009.

[7] M. Sabu, "Revision of the genus Zingiber in South India," Folia Malaysiana, vol. 4, no. 1, pp. 25-52, 2003.

[8] Y. Shukla and M. Singh, "Cancer preventive properties of ginger: a brief review," Food and Chemical Toxicology, vol. 45, no. 5, pp. 683-690, 2007.

[9] R. O. Prakash, A. Rabinarayan, and M. S. Kumar, "Zingiber zerumbet (L.) Sm., a reservoir plant for therapeutic uses: a review," International Journal of Research in Ayurveda and Pharmacy, vol. 2, pp. 1-22, 2011.

[10] D. S. Jang, A.-R. Han, G. Park, G.-J. Jhon, and E.-K. Seo, "Flavonoids and aromatic compounds from the rhizomes of Zingiber zerumbet," Archives of Pharmacal Research, vol. 27, no. 4, pp. 386-389, 2004.

[11] R. O. Prakash, R. K. Kumar, A. Rabinarayan, and M. S. Kumar, "Pharmacognostical and phytochemical studies of Zingiber zerumbet (L.) Smith rhizome," International Journal of Research in Ayurveda and Pharmacy, vol. 2, no. 3, pp. 698-703, 2011.

[12] D. S. Jang and E.-K. Seo, "Potentially bioactive two new natural sesquiterpenoids from the rhizomes of Zingiber zerumbet," Archives of Pharmacal Research, vol. 28, no. 3, pp. 294-296, 2005.

[13] S. Sultana, F. A. Ripa, and K. Hamid, "Comparative antioxidant activity study of some commonly used spices in Bangladesh," Pakistan Journal of Biological Sciences, vol. 13, no. 7, pp. 340-343, 2010.

[14] A. Sahebkar, "Potential efficacy of ginger as a natural supplement for nonalcoholic fatty liver disease," World Journal of Gastroenterology, vol. 17, no. 2, pp. 271-272, 2011.

[15] M. S. Butt and M. T. Sultan, "Ginger and its health claims: molecular aspects," Critical Reviews in Food Science and Nutrition, vol. 51, no. 5, pp. 383-393, 2011.

[16] G. Kader, F. Nikkon, M. A. Rashid, and T. Yeasmin, "Antimicrobial activities of the rhizome extract of Zingiber zerumbet Linn," Asian Pacific Journal of Tropical Biomedicine, vol. 1, no. 5, pp. 409-412, 2011.
[17] M. N. Somchit, M. H. Shukriyah, A. A. Bustamam, and A. Zuraini, "Anti-pyretic and analgesic activity of Zingiber zerumbet," International Journal of Pharmacology, vol. 1, no. 3, pp. 277280, 2005.

[18] M. Al-Amin, G. N. N. Sultana, and C. F. Hossain, "Antiulcer principle from Zingiber montanum," Journal of Ethnopharmacology, vol. 141, no. 1, pp. 57-60, 2012.

[19] M. Habsah, M. Amran, M. M. Mackeen et al., "Screening of Zingiberaceae extracts for antimicrobial and antioxidant activities," Journal of Ethnopharmacology, vol. 72, no. 3, pp. 403410, 2000.

[20] T.-F. Tzeng, S.-S. Liou, C. J. Chang, and I.-M. Liu, "The ethanol extract of Zingiber zerumbet attenuates streptozotocin-induced diabetic nephropathy in rats," Evidence-Based Complementary and Alternative Medicine, vol. 2013, Article ID 340645, 8 pages, 2013.

[21] S. I. A. Wahab, A. B. Abdul, H. C. Yeel, A. S. Alzubain, M. M. Elhassan, and M. M. Syam, "Anti-tumor activities of analogues derived from the bioactive compound of Zingiber zerumbet," International Journal of Cancer Research, vol. 4, no. 4, pp. 154159, 2008.

[22] R. A. Rashid and A. H. L. Pihie, "The antiproliferative effects of Zingiber zerumbet extracts and fractions on the growth of human breast carcinoma cell lines," Malaysian Journal of Pharmaceutical Sciences, vol. 3, no. 1, pp. 45-52, 2005.

[23] A. Rasedee, S. R. Heshu, A. Ahmad Bustamam, C. W. How, and K. Y. Swee, "A composition for treating leukaemia," Malaysian Patent Application, p. PI2013700213, 2013.

[24] M. R. Sulaiman, E. K. Perimal, M. N. Akhtar et al., "Antiinflammatory effect of zerumbone on acute and chronic inflammation models in mice," Fitoterapia, vol. 81, no. 7, pp. 855-858, 2010.

[25] Z. A. Zakaria, A. S. Mohamad, C. T. Chear, Y. Y. Wong, D. A. Israf, and M. R. Sulaiman, "Antiinflammatory and antinociceptive activities of Zingiber zerumbet methanol extract in experimental model systems," Medical Principles and Practice, vol. 19, no. 4, pp. 287-294, 2010.

[26] M. N. Somchit, J. H. Mak, A. Ahmad Bustamam et al., "Zerumbone isolated from Zingiber zerumbet inhibits inflammation and pain in rats," Journal of Medicinal Plant Research, vol. 6, pp. 177-180, 2012.

[27] M. R. Sulaiman, T. A. S. Tengku Mohamad, W. M. Shaik Mossadeq et al., "Antinociceptive activity of the essential oil of Zingiber zerumbet," Planta Medica, vol. 76, no. 2, pp. 107-112, 2010.

[28] S. Tewtrakul and S. Subhadhirasakul, "Anti-allergic activity of some selected plants in the Zingiberaceae family," Journal of Ethnopharmacology, vol. 109, no. 3, pp. 535-538, 2007.

[29] J. Rhode, S. Fogoros, S. Zick et al., "Ginger inhibits cell growth and modulates angiogenic factors in ovarian cancer cells," $B M C$ Complementary and Alternative Medicine, vol. 7, article 44, 2007.

[30] T.-F. Tzeng and I.-M. Liu, "6-Gingerol prevents adipogenesis and the accumulation of cytoplasmic lipid droplets in 3T3-L1 cells," Phytomedicine, vol. 20, no. 6, pp. 481-487, 2013.

[31] I. Jantan, S. M. Raweh, H. M. Sirat et al., "Inhibitory effect of compounds from Zingiberaceae species on human platelet aggregation," Phytomedicine, vol. 15, no. 4, pp. 306-309, 2008.

[32] A. S. El-Sharaky, A. A. Newairy, M. A. Kamel, and S. M. Eweda, "Protective effect of ginger extract against bromobenzeneinduced hepatotoxicity in male rats," Food and Chemical Toxicology, vol. 47, no. 7, pp. 1584-1590, 2009. 
[33] I. Sharma, D. Gusain, and V. P. Dixit, "Hypolipidemic and antiatherosclerotic effect of Zingiber officinale in cholesterol fed rabbits," Phytotherapy Research, vol. 10, pp. 517-518, 1996.

[34] U. Bhandari, J. N. Sharma, and R. Zafar, "The protective action of ethanolic ginger (Zingiber officinale) extract in cholesterol fed rabbits," Journal of Ethnopharmacology, vol. 61, no. 2, pp. 167171, 1998.

[35] A. K. Srivastava, S. K. Srivastava, and N. C. Shah, "Constituents of the rhizome essential oil of Curcuma amada Roxb. from India," Journal of Essential Oil Research, vol. 13, no. 1, pp. 63-64, 2001.

[36] S. Dev, "Studies in sesquiterpenes-XVI: zerumbone, a monocyclic sesquiterpene ketone," Tetrahedron, vol. 8, no. 3-4, pp. 171-180, 1960.

[37] S. Dev, J. E. Anderson, V. Cormier, N. P. Damodaran, and J. D. Roberts, "Nuclear magnetic resonance spectroscopy. The conformational mobility of humulene and zerumbone," Journal of the American Chemical Society, vol. 90, no. 5, pp. 1246-1248, 1968.

[38] T. Kitayama, T. Okamoto, R. K. Hill et al., "Chemistry of Zerumbone. 1. Simplified isolation, conjugate addition reactions, and a unique ring contracting transannular reaction of its dibromide," Journal of Organic Chemistry, vol. 64, no. 8, pp. 2667-2672, 1999.

[39] T. Kitayama, A. Furuya, C. Moriyama et al., "Elucidation of the Sharpless epoxidation of zerumbol," Tetrahedron Asymmetry, vol. 17, no. 16, pp. 2311-2316, 2006.

[40] S. R. Hall, S. Nimgirawath, C. L. Raston et al., "Crystal structure of zerumbone [(E, E, E)-2, 6, 9, 9-Tetramethylcycloundeca-2, 6, 10-trien-1-one]," Australian Journal of Chemistry, vol. 34, no. 10, pp. 2243-2247, 1981.

[41] N. P. Chhabra, R. S. Dhillon, M. S. Wadia, and P. S. Kalsi, "Structure of zerumbone oxide: a new sesquiterpene epoxy ketone from Zingiber zerumbet Smith (wild ginger oil)," Indian Journal of Chemistry, vol. 13, pp. 222-224, 1975.

[42] H. N. S. Rao, N. P. Damodaran, and S. Dev, "Photochemistry of zerumbone," Tetrahedron Letters, vol. 8, no. 3, pp. 227-233, 1967.

[43] N. P. Damodaran and S. Dev, "Stereochemistry of zerumbone," Tetrahedron Letters, vol. 6, no. 24, pp. 1977-1981, 1965.

[44] S. Baby, M. Dan, A. R. M. Thaha et al., "High content of zerumbone in volatile oils of Zingiber zerumbet from southern India and Malaysia," Flavour and Fragrance Journal, vol. 24, no. 6, pp. 301-308, 2009.

[45] I. Lechat-Vahirua, P. Francois, C. Menut, G. Lamaty, and J.-M. Bessiere, "Aromatic plants of French Polynesia. I. Constituents of the essential oils of rhizomes of three Zingiberaceae: Zingiber zerumbet Smith, Hedychium coronarium Koenig and Etlingera cevuga Smith," Journal of Essential Oil Research, vol. 5, no. 1, pp. 55-59, 1993.

[46] N. X. Dung, T. D. Chinh, D. D. Rang, and P. A. Leclercq, "'The constituents of the rhizome oil of Zingiber zerumbet (L.) Sm. from Vietnam," Journal of Essential Oil Research, vol. 5, no. 5, pp. 553-555, 1993.

[47] P. M. Giang, P. T. Son, H. Z. Jin, J. H. Lee, and J. J. Lee, “Comparative study on inhibitory activity of zerumbone and zerumbone 2,3-epoxide on NF- $\kappa$ B activation and NO production," Scientia Pharmaceutica, vol. 77, no. 3, pp. 589-595, 2009.

[48] J. Chane-Ming, R. Vera, and J.-C. Chalchat, "Chemical composition of the essential oil from rhizomes, leaves and flowers of Zingiber zerumbet smith from Reunion Island," Journal of Essential Oil Research, vol. 15, no. 3, pp. 202-205, 2003.
[49] S. Riyanto, Phytochemical studies and bioactivity tests of Murraya paniculata Jack, Aegle marmelos Correa and Zingiber amaricans Blume [M.S. thesis], Universiti Putra Malaysia, 2003.

[50] H. M. Sirat and A. B. Nordin, "Essential oil of Zingiber ottensii valeton," Journal of Essential Oil Research, vol. 6, no. 6, pp. 635636, 1994.

[51] A. M. S. Muhammad, A study on microwave-assisted extraction of Zingiber aromaticum. Faculty of Chemical \& Natural Resources Engineering, 2009.

[52] N. Kishore and R. S. Dwivedi, "Zerumbone: a potential fungitoxic agent isolated from Zingiber cassumunar Roxb," Mycopathologia, vol. 120, no. 3, pp. 155-159, 1992.

[53] S. Thubthimthed, P. Limsiriwong, U. Rerk-Am, and T. Suntorntanasat, "Chemical composition and cytotoxic activity of the essential oil of Zingiber ottensii," in Proceedings of the 3rd World Congress on Medicinal and Aromatic Plants-Volume 1: Bioprospecting and Ethnopharmacology (WOCMAP '03), vol. 675, pp. 107-109, 2003.

[54] L. S. R. Arambewela, M. Arawwawala, N. L. Owen, and B. Jarvis, "Volatile oil of Alpinia galanga willd. of Sri Lanka," Journal of Essential Oil Research, vol. 19, no. 5, pp. 455-456, 2007.

[55] I. A. Ogunwande, N. O. Olawore, and K. A. Adeleke, "Contribution to the study of essential oil of Xylopia aethiopica (DUNAL) A. RICH: isolation and characterization of zerumbone," Journal of Essential Oil Bearing Plants, vol. 8, no. 2, pp. 159-164, 2005.

[56] S. Kapoor, "The rapidly emerging role of zerumbone in attenuating tumor growth in systemic malignancies," Molecular Nutrition and Food Research, vol. 56, no. 10, pp. 1487-1487, 2012.

[57] S. K. Sadhu, A. Khatun, T. Ohtsuki, and M. Ishibashi, "First isolation of sesquiterpenes and flavonoids from Zingiber spectabile and identification of zerumbone as the major cell growth inhibitory component," Natural Product Research, vol. 21, no. 14, pp. 1242-1247, 2007.

[58] H. S. Rahman, A. Rasedee, C. W. How et al., "Zerumboneloaded nanostructured lipid carriers: preparation, characterization, and antileukemic effect," International Journal of Nanomedicine, vol. 8, pp. 2769-2781, 2013.

[59] R. Prasannan, K. A. Kalesh, M. K. Shanmugam et al., "Key cell signaling pathways modulated by zerumbone: role in the prevention and treatment of cancer," Biochemistry and Pharmacology, vol. 84, no. 10, pp. 1268-1276, 2012.

[60] A. Hoffman, L. M. Spetner, and M. Burke, "Redox-regulated mechanism may account for zerumbone's ability to suppress cancer-cell proliferation (multiple letters)," Carcinogenesis, vol. 23, no. 11, pp. 1961-1962, 2002.

[61] A. Murakami, D. Takahashi, T. Kinoshita et al., "Zerumbone, a Southeast Asian ginger sesquiterpene, markedly suppresses free radical generation, proinflammatory protein production, and cancer cell proliferation accompanied by apoptosis: the $\alpha, \beta$ unsaturated carbonyl group is a prerequisite," Carcinogenesis, vol. 23, no. 5, pp. 795-802, 2002.

[62] P. A. Cerutti and B. F. Trump, "Inflammation and oxidative stress in carcinogenesis," Cancer Cells, vol. 3, no. 1, pp. 1-7, 1991.

[63] Y. Takada, A. Murakami, and B. B. Aggarwal, "Zerumbone abolishes NF- $\kappa \mathrm{B}$ and $\mathrm{I} \kappa \mathrm{B} \alpha$ kinase activation leading to suppression of antiapoptotic and metastatic gene expression, upregulation of apoptosis, and downregulation of invasion," Oncogene, vol. 24, no. 46, pp. 6957-6969, 2005.

[64] B. Sung, S. Jhurani, S. A. Kwang et al., "Zerumbone downregulates chemokine receptor CXCR4 expression leading to inhibition of CXCL12-induced invasion of breast and pancreatic 
tumor cells," Cancer Research, vol. 68, no. 21, pp. 8938-8944, 2008.

[65] S. I. Abdelwahab, A. B. Abdul, S. Mohan et al., "Zerumbone induces apoptosis in T-acute lymphoblastic leukemia cells," Leukemia Research, vol. 35, no. 2, pp. 268-271, 2011.

[66] H. S. Rahman, A. Rasedee, C. W. How et al., "Zerumboneloaded nanostructured lipid carriers: preparation, characterization, and antileukemic effect," International Journal of Nanomedicine, vol. 8, pp. 2769-2781, 2013.

[67] M. Xian, K. Ito, T. Nakazato et al., "Zerumbone, a bioactive sesquiterpene, induces G2/M cell cycle arrest and apoptosis in leukemia cells via a Fas- and mitochondria-mediated pathway," Cancer Science, vol. 98, no. 1, pp. 118-126, 2007.

[68] B. Sung, A. Murakami, B. O. Oyajobi, and B. B. Aggarwal, "Zerumbone abolishes RaNKL-induced NF- $\kappa$ B activation, inhibits osteoclastogenesis, and suppresses human breast cancer-induced bone loss in athymic nude mice," Cancer Research, vol. 69, no. 4, pp. 1477-1484, 2009.

[69] G.-C. Huang, T.-Y. Chien, L.-G. Chen, and C.-C. Wang, "Antitumor effects of zerumbone from Zingiber zerumbet in P-388D1 cells in vitro and in vivo," Planta Medica, vol. 71, no. 3, pp. 219224, 2005.

[70] H. S. Rahman, A. Rasedee, B. A. Ahmad, H. O. Hemn, N. A. Zeenathul, and J. A. Reena, "Zerumbone regulate the expression of apoptotic biomarkers in BALB/C mice model of leukemia," in Proceedings of the 1st International Conference on Molecular Diagnostics and Biomarker Discovery, Equatorial Hotel, Penang, Malaysia, 2013.

[71] A. S. Al-Zubairi, A. B. Abdul, and M. M. Syam, "Evaluation of the genotoxicity of zerumbone in cultured human peripheral blood lymphocytes," Toxicology in Vitro, vol. 24, no. 3, pp. 707712, 2010.

[72] H. S. Rahman, R. Abdullah, B. A. Ahmad et al., "Zerumboneloaded nanostructured lipid carrier induces G2/M cell cycle arrest and apoptosis via mitochondrial pathway in human lymphoblastic leukemia cell line," International Journal Nanomedicine, vol. 9, pp. 527-538, 2014.

[73] Y. S. Keong, N. B. Alitheen, S. Mustafa, S. A. Aziz, M. A. Rahman, and A. M. Ali, "Immunomodulatory effects of zerumbone isolated from roots of Zingiber zerumbet," Pakistan Journal of Pharmaceutical Sciences, vol. 23, no. 1, pp. 75-82, 2010.

[74] A. S. Al-Zubairi, S. Adel, A. B. Abdul et al., "In vivo and in vitro genotoxic effects of zerumbone," Caryologia, vol. 63, no. 1, pp. $11-17,2010$.

[75] A. Eguchi, Y. Kaneko, A. Murakami, and H. Ohigashi, "Zerumbone suppresses phorbol ester-induced expression of multiple scavenger receptor genes in THP-1 human monocytic cells," Bioscience, Biotechnology and Biochemistry, vol. 71, no. 4, pp. 935-945, 2007.

[76] A. Sehrawat, J. A. Arlotti, A. Murakami, and S. V. Singh, "Zerumbone causes Bax- and Bak-mediated apoptosis in human breast cancer cells and inhibits orthotopic xenograft growth in vivo," Breast Cancer Research and Treatment, vol. 136, no. 2, pp. 429-441, 2012.

[77] Y. Ni, In vitro and in vivo studies of pharmacological effects of zerumbone on human malignant melanoma [Ph.D. thesis], 2013.

[78] J.-W. Shin, K. Ohnishi, A. Murakami et al., "Zerumbone induces heme oxygenase-1 expression in mouse skin and cultured murine epidermal cells through activation of Nrf2," Cancer Prevention Research, vol. 4, no. 6, pp. 860-870, 2011.
[79] S. A. S. Sakinah, S. T. Handayani, and L. P. A. Hawariah, "Zerumbone induced apoptosis in liver cancer cells via modulation of Bax/ Bcl-2 ratio," Cancer Cell International, vol. 7, no. 4, pp. 1-11, 2007.

[80] H. W. D. Matthes, B. Luu, and G. Ourisson, "Cytotoxic components of Zingiber zerumbet, Curcuma zedoaria and C. domestica," Phytochemistry, vol. 19, no. 12, pp. 2643-2650, 1980.

[81] H. W. D. Matthes, B. Luu, and G. Ourisson, "Transannular cyclizations of zerumbone epoxide," Tetrahedron, vol. 38, no. 21, pp. 3129-3135, 1982.

[82] K. Ohnishi, K. Irie, and A. Murakami, "Modulation of protein quality control systems as novel mechanisms underlying functionality of food phytochemicals," Functional Food in Health and Disease, vol. 3, no. 10, pp. 400-415, 2013.

[83] K. Ohnishi, E. Nakahata, K. Irie, and A. Murakami, "Zerumbone, an electrophilic sesquiterpene, induces cellular proteostress leading to activation of ubiquitin-proteasome system and autophagy," Biochemical and Biophysical Research Communications, vol. 430, no. 2, pp. 616-622, 2013.

[84] K. Ohnishi, S. Ohkura, E. Nakahata et al., "Non-specific protein modifications by a phytochemical induce heat shock response for self-defense," PLoS ONE, vol. 8, no. 3, Article ID e58641, 2013.

[85] Y. Nakamura, C. Yoshida, A. Murakami, H. Ohigashi, T. Osawa, and K. Uchida, "Zerumbone, a tropical ginger sesquiterpene, activates phase II drug metabolizing enzymes," FEBS Letters, vol. 572, no. 1-3, pp. 245-250, 2004.

[86] A. S. Nozlena, B. A. Ahmad, A. Rasedee et al., "Cytotoxicity of zerumbone against liver cancer cell lines (HepG2) via apoptosis activity," Scientific Cancer Research Poster Competition in Conjunction With Cancer Carnival. Faculty of Medicine and Health Sciences, Universiti Putra Malaysia, Selangor, Malaysia, 2014.

[87] S. I. Abdelwahab, A. B. Abdul, Z. N. M. Zain, and A. H. A. Hadi, "Zerumbone inhibits interleukin- 6 and induces apoptosis and cell cycle arrest in ovarian and cervical cancer cells," International Immunopharmacology, vol. 12, no. 4, pp. 594-602, 2012.

[88] S. I. Abdelwahab, A. B. Abdul, N. Devi et al., "Regression of cervical intraepithelial neoplasia by zerumbone in female Balb/c mice prenatally exposed to diethylstilboestrol: involvement of mitochondria-regulated apoptosis," Experimental and Toxicologic Pathology, vol. 62, no. 5, pp. 461-469, 2010.

[89] N. Devi Tailan, Effects of zerumbone from Zingiber zerumbet on cervical cancer-induced female Balb/C mice [M.S. thesis], Universiti Putra Malaysia, 2007.

[90] S. Yodkeeree, B. Sung, P. Limtrakul, and B. B. Aggarwal, "Zerumbone enhances TRAIL-induced apoptosis through the induction of death receptors in human colon cancer cells: evidence for an essential role of reactive oxygen species," Cancer Research, vol. 69, no. 16, pp. 6581-6589, 2009.

[91] A. Deorukhkar, N. Ahuja, A. Mercado et al., "Zerumbone, a sesquiterpene from southeast Asian edible ginger sensitizes colorectal cancer cells to radiation therapy," International Journal of Radiation Oncology ${ }^{*}$ Biology ${ }^{*}$ Physics, vol. 78, no. 3, p. S654, 2010.

[92] U. Songsiang, S. Pitchuanchom, C. Boonyarat, C. Hahnvajanawong, and C. Yenjai, "Cytotoxicity against cholangiocarcinoma cell lines of zerumbone derivatives," European Journal of Medicinal Chemistry, vol. 45, no. 9, pp. 3794-3802, 2010. 
[93] A. S. Al-Zubairi, "Genotoxicity assessment of a natural anticancer compound zerumbone in CHO cell lines," International Journal of Cancer Research, vol. 8, no. 4, pp. 119-129, 2012.

[94] A. Chakraborty, R. Coffman, and J. Jorvig, "Zerumbone, a phytochemical from Asian ginger is a novel inhibitor of Jak2/Stat3 inhibits promigratory gene expression, growth and migration of pancreatic cancer cells," Pancreatology, vol. 13, no. 2, pp. e18-e19, 2013.

[95] S. Zhang, Q. Liu, Y. Liu, H. Qiao, and Y. Liu, "Zerumbone, a Southeast Asian ginger sesquiterpene, induced apoptosis of pancreatic carcinoma cells through p53 signaling pathway," Evidence-Based Complementary and Alternative Medicine, vol. 2012, Article ID 936030, 8 pages, 2012.

[96] T. Shamoto, Y. Matsuo, T. Shibata et al., "Zerumbone inhibits angiogenesis by blocking NF- $\kappa \mathrm{B}$ activity in pancreatic cancer," Pancreas, vol. 43, no. 3, pp. 396-404, 2014.

[97] S. Pitchuanchom, U. Songsiang, N. Weerapreeyakul, and C. Yenjai, "Anticancer activity of the bioreductive and nonbioreductive zerumbone derivatives," Letters in Drug Design and Discovery, vol. 8, no. 6, pp. 536-543, 2011.

[98] C. Tang, M. Bi, H. Yu, W. Chen, and J. Wang, "Zerumbone protects HEK 293 cells from irradiation-induced DNA damage via activating Keap1/Nrf2/ARE pathway," African Journal of Pharmacy and Pharmacology, vol. 5, no. 20, pp. 2247-2254, 2011.

[99] H.-Y. Weng, M.-J. Hsu, C.-C. Wang et al., "Zerumbone suppresses IKK $\alpha$, Akt, and FOXO1 activation, resulting in apoptosis of GBM 8401 cells," Journal of Biomedical Science, vol. 19, no. 1, pp. 1-11, 2012.

[100] K. Tsuboi, Y. Matsuo, T. Shamoto et al., "Zerumbone inhibits tumor angiogenesis via NF- $\kappa \mathrm{B}$ in gastric cancer," Oncology Report, vol. 3, no. 1, pp. 57-64, 2014.

[101] C. Kirana, G. H. Mcintosh, I. R. Record, and G. P. Jones, "Antitumor activity of extract of Zingiber aromaticum and its bioactive sesquiterpenoid zerumbone," Nutrition and Cancer, vol. 45, no. 2, pp. 218-225, 2003.

[102] M. Kim, S. Miyamoto, Y. Yasui, T. Oyama, A. Murakami, and T. Tanaka, "Zerumbone, a tropical ginger sesquiterpene, inhibits colon and lung carcinogenesis in mice," International Journal of Cancer, vol. 124, no. 2, pp. 264-271, 2009.

[103] A. Murakami, R. Hayashi, T. Takana, K. H. Kwon, H. Ohigashi, and R. Safitri, "Suppression of dextran sodium sulfateinduced colitis in mice by zerumbone, a subtropical ginger sesquiterpene, and nimesulide: separately and in combination," Biochemical Pharmacology, vol. 66, no. 7, pp. 1253-1261, 2003.

[104] T. Tanaka, M. Shimizu, H. Kohno et al., "Chemoprevention of azoxymethane-induced rat aberrant crypt foci by dietary zerumbone isolated from Zingiber zerumbet," Life Sciences, vol. 69, no. 16, pp. 1935-1945, 2001.

[105] M. M. E. Taha, A. B. Abdul, R. Abdullah, T. A. T. Ibrahim, S. I. Abdelwahab, and S. Mohan, "Potential chemoprevention of diethylnitrosamine-initiated and 2-acetylaminofluorenepromoted hepatocarcinogenesis by zerumbone from the rhizomes of the subtropical ginger (Zingiber zerumbet)," ChemicoBiological Interactions, vol. 186, no. 3, pp. 295-305, 2010.

[106] S. Fakurazi, I. Hairuszah, J. Mohd Lip et al., "Hepatoprotective action of zerumbone against paracetamol induced hepatotoxicity," Journal of Medical Sciences, vol. 9, no. 3, pp. 161-164, 2009.

[107] S. Fakurazi, I. Hairuszah, J. M. Lip, and G. Shanthi, "The effect of pretreatment of zerumbone on fatty liver following ethanol induced hepatoxicity," Journal of Biological Sciences, vol. 8, no. 8, pp. 1348-1351, 2008.
[108] T. F. Tzeng, S. S. Liou, C. J. Chang, and I. M. Liu, "Zerumbone, a natural cyclic sesquiterpene of Zingiber zerumbet Smith, attenuates nonalcoholic fatty liver disease in hamsters fed on high-fat diet," Evidence-Based Complementary and Alternative Medicine, vol. 2013, Article ID 303061, 9 pages, 2013.

[109] A. E. Safa, Zerumbone and small interference RNA induce apoptosis in MCF-7 cell and rat mammary gland tumour via $\beta$-Catenin protein inhibition [Ph.D. thesis], Universiti Puta Malaysia, 2013.

[110] A. Murakami, M. Miyamoto, and H. Ohigashi, "Zerumbone, an anti-inflammatory phytochemical, induces expression of proinflammatory cytokine genes in human colon adenocarcinoma cell lines," BioFactors, vol. 21, no. 1-4, pp. 95-101, 2004.

[111] B.-Y. Chen, D. P.-C. Lin, C.-Y. Wu et al., "Dietary zerumbone prevents mouse cornea from UVB-induced photokeratitis through inhibition of NF- $\kappa \mathrm{B}$, iNOS, and TNF- $\alpha$ expression and reduction of MDA accumulation," Molecular Vision, vol. 17, pp. 854-863, 2011.

[112] B.-Y. Chen, D. P.-C. Lin, K.-C. Su et al., "Dietary zerumbone prevents against ultraviolet B-induced cataractogenesis in the mouse," Molecular Vision, vol. 17, pp. 723-730, 2011.

[113] A. Szabolcs, L. Tiszlavicz, J. Kaszaki et al., "Zerumbone exerts a beneficial effect on inflammatory parameters of cholecystokinin octapeptide-induced experimental pancreatitis but fails to improve histology," Pancreas, vol. 35, no. 3, pp. 249-255, 2007.

[114] D. Wenhong, Y. Jia, W. Weixing et al., "Zerumbone attenuates the severity of acute necrotizing pancreatitis and pancreatitisinduced hepatic injury," Mediators of Inflammation, vol. 2012, Article ID 156507, 2012.

[115] S. Ganabadi, S. Kadir, and A. A. Fakurazi, "Zerumbone's effect on major histocompatibility complex type II cells in synovial membrane of osteoArthritic joint," Research Journal of Veterinary Sciences, vol. 2, no. 1, pp. 14-20, 2009.

[116] F. J. Al-Saffar, S. Ganabadi, S. Fakurazi, H. Yaakub, and M. Lip, "Chondroprotective effect of zerumbone on monosodium iodoacetate induced osteoarthritis in rats," Journal of Applied Sciences, vol. 10, no. 4, pp. 248-260, 2010.

[117] F. J. Al-saffar, S. Ganabadi, S. Fakurazi, and H. Yaakub, "Zerumbone significantly improved immunoreactivity in the synovium compared to Channa striatus extract in monosodium iodoacetate (MIA)-induced knee osteoarthritis in rat," Journal of Medicinal Plants Research, vol. 5, no. 9, pp. 1701-1710, 2011.

[118] E. K. Perimal, M. N. Akhtar, A. S. Mohamad et al., "ZerumboneInduced Antinociception: involvement of the l-Arginine-Nitric Oxide-cGMP -PKC-K+ATP Channel Pathways," Basic and Clinical Pharmacology and Toxicology, vol. 108, no. 3, pp. 155162, 2011.

[119] M. R. Sulaiman, E. K. Perimal, Z. A. Zakaria et al., "Preliminary analysis of the antinociceptive activity of zerumbone," Fitoterapia, vol. 80, no. 4, pp. 230-232, 2009.

[120] H. S. Rahman, R. Abdullah, H. H. Othman et al., "Acute toxicity study of zerumbone-loaded nanostructured lipid carrier on $\mathrm{BALB} / \mathrm{c}$ mice model," BioMed Research International. In press.

[121] Y. B. Jin, W. D. Seo, Y. J. Lee, Y. S. Lee, and H. J. Lee, "Toxicological evaluation of zerumbone on antitumor effects in mice," African Journal of Pharmacy and Pharmacology, vol. 7, no. 8, pp. 466-473, 2013.

[122] M. Y. Ibrahim, A. B. H. Abdul, T. A. T. Ibrahim, S. I. Abdelwahab, M. M. Elhassan, and M. M. Syam, "Evaluation of acute toxicity and the effect of single injected doses of zerumbone on the kidney and liver functions in Sprague Dawley rats," African Journal of Biotechnology, vol. 9, no. 28, pp. 4442-4450, 2010. 
[123] M. Y. Ibrahim, A. B. H. Abdul, T. A. T. Ibrahim, S. I. AbdelWahab, M. M. Elhassan, and S. Mohan, "Attenuation of cisplatin-induced nephrotoxicity in rats using zerumbone," African Journal of Biotechnology, vol. 9, no. 28, pp. 4434-4441, 2010.

[124] H. O. Hemn, H. Hazilawati, M. M. Noordin, and S. R. Heshu, "Proteomic evaluation and validation of anti-inflammatory and anti-proliferative properties of zerumbone in atheroscleroticinduced New Zealand white rabbit," in Proceedings of the 1st Malaysian Proteonomics Conference (MPC '12), Penang, Malaysia, 2012.

[125] T. F. Tzeng, H. J. Lu, S. S. Liou, C. J. Chang, and I. M. Liu, "Lipidlowering effects of zerumbone, a natural cyclic sesquiterpene of Zingiber zerumbet Smith, in high-fat diet-induced hyperlipidemic hamsters," Food and Chemical Toxicology, vol. 69, pp. 132139, 2014.

[126] N. B. Alitheen, S. K. Yeap, N. H. Faujan, W. Y. Ho, B. K. Beh, and A. R. Mashitoh, "Leukemia and therapy," American Journal of Immunology, vol. 7, no. 4, pp. 54-61, 2011.

[127] A. Murakami, T. Tanaka, J.-Y. Lee et al., "Zerumbone, a sesquiterpene in subtropical ginger, suppresses skin tumor initiation and promotion stages in ICR mice," International Journal of Cancer, vol. 110, no. 4, pp. 481-490, 2004.

[128] C. Liu, Molecular Mechanisms of Inhibitory Effect of Zerumbone on Human Malignant Melanoma Cells, Emporia State University, 2011.

[129] S. S. Alwi, M. Nallappan, A. Hawariah, and L. Pihie, "Zerumbone exerts antiproliferative activity via apoptosis on HepG2 cells," Malaysian Journal of Biochemistry and Molecular Biology, vol. 15, no. 1, pp. 19-23, 2007.

[130] A. Bustamam, S. Ibrahim, N. Devi, M. N. Halkim, A. S. AlZubairi, and M. M. Syam, "The establishment and use of an in vivo animal model for cervical intra-epithelial neoplasia," International Journal of Cancer Research, vol. 4, no. 3, pp. 61-70, 2008.

[131] A. B. Abdul, S. I. Abdelwahab, J. B. Jalinas, A. S. Al-Zubairi, and M. M. E. Taha, "Combination of zerumbone and cisplatin to treat cervical intraepithelial neoplasia in female BALB/c mice," International Journal of Gynecological Cancer, vol. 19, no. 6, pp. 1004-1010, 2009.

[132] A. Murakami, M. Takahashi, S. Jiwajinda, K. Koshimizu, and H. Ohigashi, "Identification of zerumbone in Zingiber zerumbet Smith as a potent inhibitor of 12-O-tetradecanoylphorbol13-acetate-induced Epstein-Barr virus activation," Bioscience, Biotechnology and Biochemistry, vol. 63, no. 10, pp. 1811-1812, 1999.

[133] M. Kim, S. Miyamoto, Y. Yasui, T. Oyama, A. Murakami, and T. Tanaka, "Zerumbone, a tropical ginger sesquiterpene, inhibits colon and lung carcinogenesis in mice," International Journal of Cancer, vol. 124, no. 2, pp. 264-271, 2009.

[134] A. Chakraborty and J. Jorvig, "Zerumbone, a phytochemical from asian ginger inhibits JAK/STAT pathway, growth, apoptosis and increase taxol sensitivity of hormone refractory prostate cancer cells," Cancer Research, vol. 71, supplement 1, no. 8, 2011.

[135] K. Tsuboi, Y. Matsuo, T. Shamoto et al., "Zerumbone inhibits tumor angiogenesis in gastric cancer," Journal of Surgical Research, vol. 172, no. 2, pp. 193-193, 2012.

[136] A. Murakami and H. Ohigashi, "Cancer-preventive antioxidants that attenuate free radical generation by inflammatory cells," Biological Chemistry, vol. 387, no. 4, pp. 387-392, 2006.

[137] K. Yamamoto, T. Kitayama, S. Minagawa et al., "Antibacterial agents that inhibit histidine protein kinase YycG of Bacillus subtilis," Bioscience, Biotechnology and Biochemistry, vol. 65, no. 10, pp. 2306-2310, 2001.

[138] T. Kitayama, R. Iwabuchi, S. Minagawa et al., "Unprecedented olefin-dependent histidine-kinase inhibitory of zerumbone ring-opening material," Bioorganic and Medicinal Chemistry Letters, vol. 14, no. 23, pp. 5943-5946, 2004.

[139] A. B. Abdul, S. I. Abdelwahab, A. S. Al-Zubaira, M. M. Elhassan, and S. M. Murali, "Anticancer and antimicrobial activities of zerumbone from the rhizomes of Zingiber zerumbut," International Journal of Pharmacology, vol. 4, no. 4, pp. 301-304, 2008.

[140] S. C. Santosh Kumar, P. Srinivas, P. S. Negi, and B. K. Bettadaiah, "Antibacterial and antimutagenic activities of novel zerumbone analogues," Food Chemistry, vol. 141, no. 2, pp. 1097-1103, 2013.

[141] U. Sriphanaa, S. Pitchuanchoma, P. Kongsaereeb, and C. Yenjaia, "Antimalarial activity and cytotoxicity of zerumbone derivatives," ScienceAsia, vol. 39, no. 1, pp. 95-99, 2013.

[142] C. J. Chang, T.-F. Tzeng, S.-S. Liou, Y.-S. Chang, and I.-M. Liu, "Absence of genotoxic and mutagenic effects of Zingiber zerumbet (L.) Smith (Zingiberaceae) extract," Evidence-Based Complementary and Alternative Medicine, vol. 2012, Article ID 406296, 9 pages, 2012.

[143] A. A. Bustamam, S. Ibrahim, A. S. Al-Zubairi, M. Met, and M. M. Syam, "Zerumbone: a natural compound with anticholinesterase activity," American Journal of Pharmacology and Toxicology, vol. 3, no. 3, pp. 209-211, 2008.

[144] S. Jagtap, K. Meganathan, V. Wagh, J. Winkler, J. Hescheler, and A. Sachinidis, "Chemoprotective mechanism of the natural compounds, epigallocatechin-3-O-gallate, quercetin and curcumin against cancer and cardiovascular diseases," Current Medicinal Chemistry, vol. 16, no. 12, pp. 1451-1462, 2009.

[145] J. B. Jagananth and L. T. Ng, Herbs: The Green Pharmacy of Malaysia, Vinpress Sdn. Bhd. and Malaysian Agricultural Research and Development Institute (MARDI), Kuala Lumpur, Malaysia, 2000.

[146] I. H. Burkill, W. Birtwistle, F. W. Foxworthy, J. B. Scrivenor, and J. G. Watson, A Dictionary of the Economic Products of the Malay Peninsula, Governments of Malaysia and Singapore by the Ministry of Agriculture and cooperatives, 1966.

[147] G. C. C. Lim, "Overview of cancer in Malaysia," Japanese Journal of Clinical Oncology, vol. 32, no. 1, pp. S37-42, 2002.

[148] E. E. M. Eid, A. B. Abdul, F. E. O. Suliman, M. A. Sukari, A. Rasedee, and S. S. Fatah, "Characterization of the inclusion complex of zerumbone with hydroxypropyl- $\beta$-cyclodextrin," Carbohydrate Polymers, vol. 83, no. 4, pp. 1707-1714, 2011.

[149] N. Muhammad Nadzri, A. B. Abdul, M. A. Sukari et al., "Inclusion complex of zerumbone with hydroxypropyl- $\beta$ Cyclodextrin induces apoptosis in liver hepatocellular HepG2 Cells via caspase 8/BID cleavage switch and modulating $\mathrm{Bcl} 2 / \mathrm{Bax}$ ratio," Evidence-Based Complementary and Alternative Medicine, vol. 2013, Article ID 810632, 16 pages, 2013. 

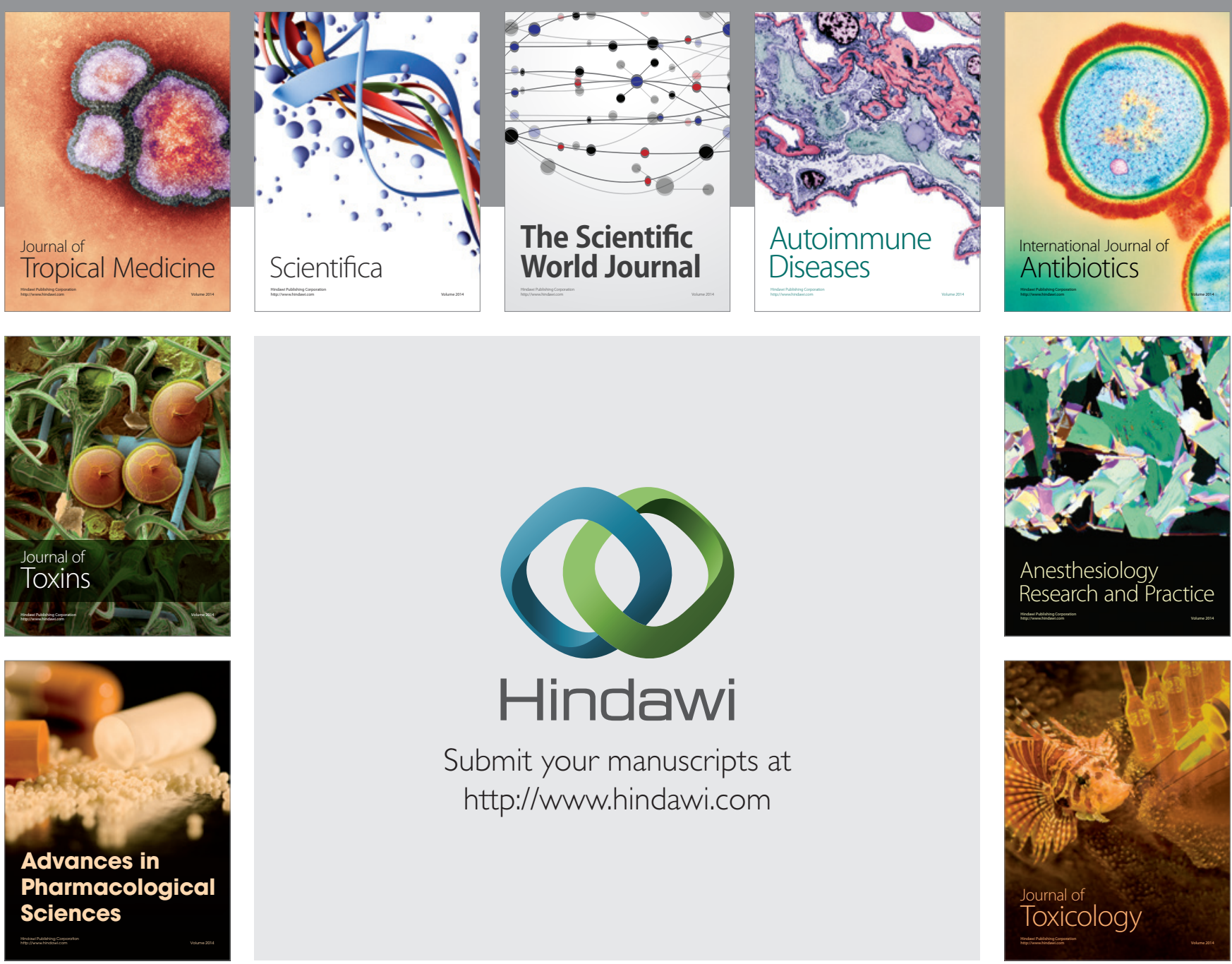

\section{Hindawi}

Submit your manuscripts at

http://www.hindawi.com
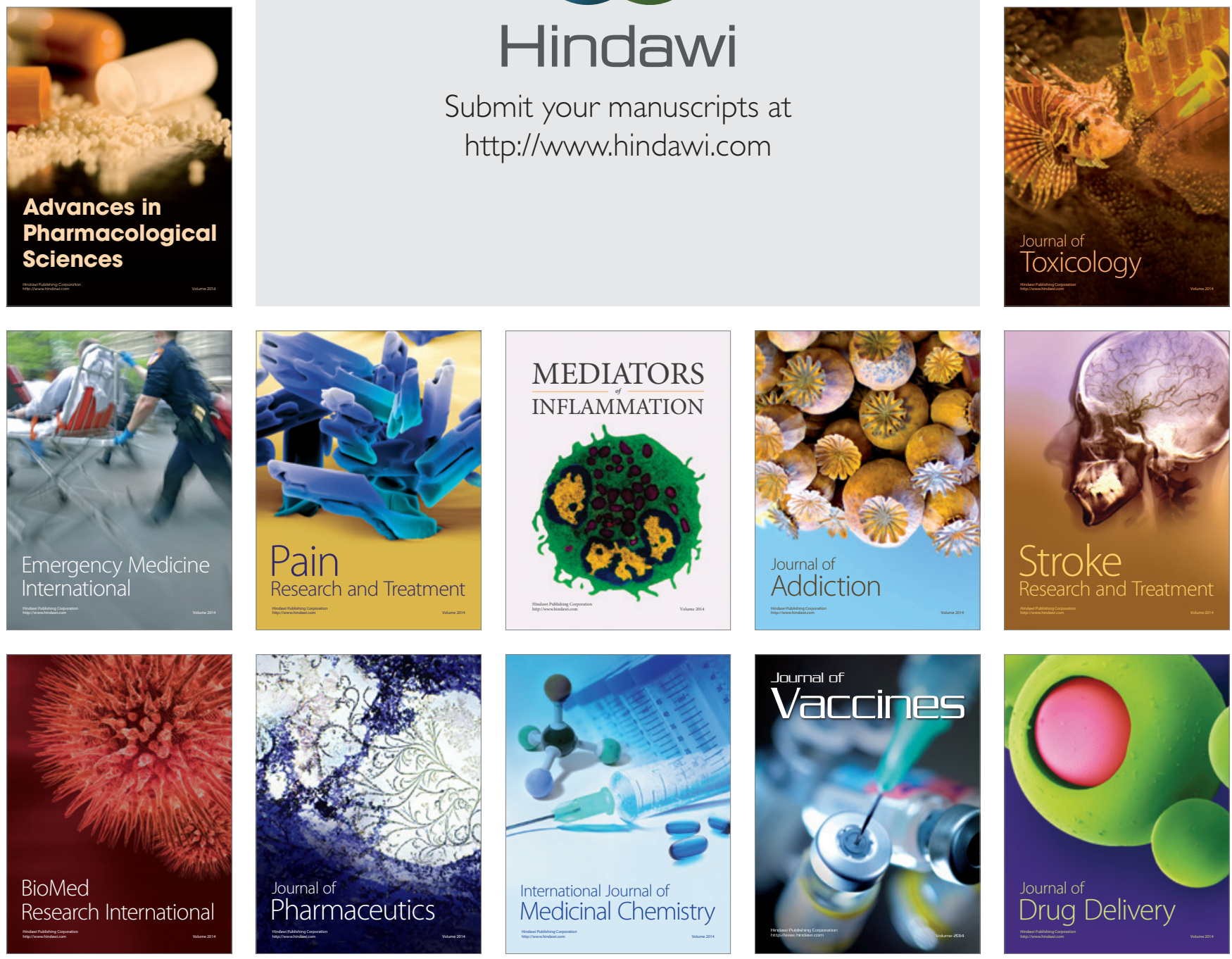